\title{
Panduan Pendamping \\ Penilaian Dasar Kesejahteraan Manusia
}

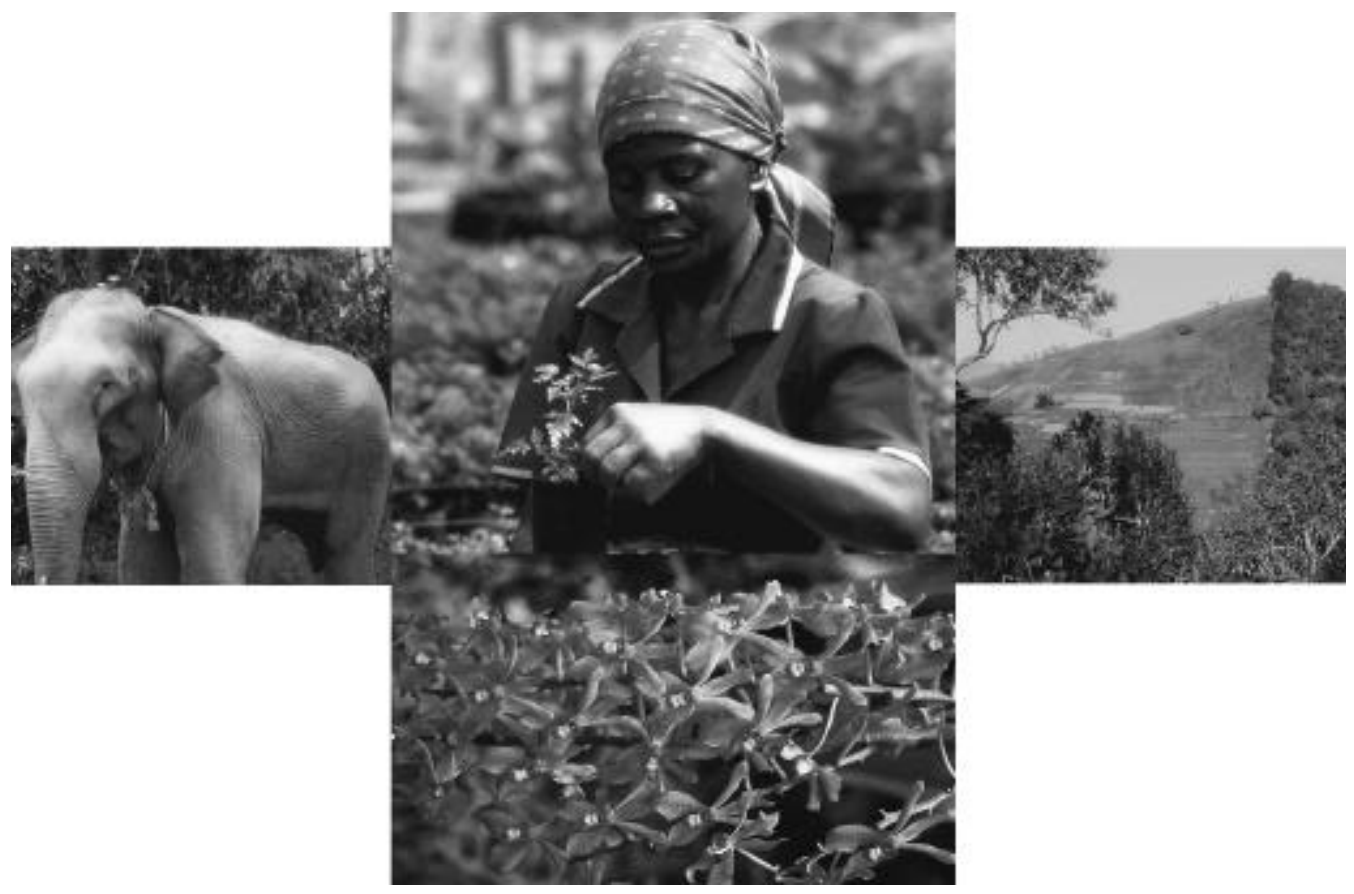

6 Perangkat Kriteria dan Indikator 


\section{Panduan Pendamping \\ Penilaian Dasar Kesejahteraan Manusia}

Oleh Tim CIFOR untuk Pengujian Metode

Carol J. Pierce Colfer, Mary Ann Brocklesby, Chimère Diaw, Priscilia Etuge, Mario Günter, Emily Harwell, Cynthia McDougall, Noemi Miyasaka Porro, Roberto Porro, Ravi Prabhu, Agus Salim, Mustofa Agung Sardjono, Bertin Tchikangwa, Anne Marie Tiani, Reed Wadley, Joe Woelfel dan Eva Wollenberg

Alih bahasa

Ani Kartikasari dan Meiske D. Tapilatu 
(C) 1999 olehCenter for International Forestry Research

Dicetak oleh SMK GrafikaMardi Yuana, Bogor

Fotografi

Bimal, Forest Departemen Elephant, India oleh Ravi Prabhu

Bwindi Forest, Uganda olehCaroline Harcourt

Seorang wanita lokal di Zimbabwe oleh David Reed (IUCN/WWF)

Dendrobium sp. (Anggrek liar) oleh Plinio Sist

Para penulis ingin menyatakan penghargaan kepada Herlina Hartanto, Herry Purnomo, Daju Pradnja Resosudarmo, Rahayu Koesnadi, Agus Salim, Abdurrahman Syebubakar, Meilinda Wan dan Yurdi Yasmi yang melakukan pengecekan kualitas terjemahan seri perangkat ini, dan juga kepada Meiske D. Tapilatu dan Dwiati Novita Rini yang melakukan pengecekan selama proses persiapan pencetakan.

ISBN: 979-8764-38-2

Diterbitkan oleh

Center for International Forestry Research (CIFOR)

Alamat: POBox6596JKPWB, Jakarta 10065, Indonesia

Telepon:+62-251-622 622 Fax: +62-251-622 100

E-mail: cifor@cgiar.org

WWW: http://www.cgiar.org/cifor

Dengan dukungan dana dari

The EuropeanCommission

Anggaran B7-6021 yang berkaitan dengan 'Hutan Tropis'

Brusel, Belgia

Deutsche Gesellschaft für Technische Zusammenarbeit (GTZ) GmbH Eschborn, Jerman

United StatesAgency for InternationalDevelopment (USAID)

Washington D.C.,Amerika Serikat

Pencetakan edisi bahasa Indonesia ini sebagian besar didanai oleh kantor Ford Foundation di Indonesia. 


\section{Seri Perangkat K\&I}

\begin{tabular}{ll}
\hline Perangkat K\&I No. 1 & $\begin{array}{l}\text { Panduan untuk Pengembangan, Pengujian dan Pemilihan } \\
\text { Kriteria dan Indikator untuk Pengelolaan Hutan Lestari } \\
\text { Prabhu, R., Colfer, C.J.P. dan Dudley, R.G. }\end{array}$ \\
\hline Perangkat K\&I No. 2 & $\begin{array}{l}\text { Acuan Generik Kriteria dan Indikator CIFOR } \\
\text { Tim KEI CIFOR }\end{array}$ \\
\hline Perangkat K\&I No. 3 & $\begin{array}{l}\text { Perangkat Modifikasi dan Adaptasi Kriteria dan Indikator } \\
\text { (CD-ROM) } \\
\text { Prabhu, R., Haggith, M., Purnomo, H., Rizal, A., Sukadri, } \\
\text { D., Taylor, J. dan Yasmi, Y. }\end{array}$
\end{tabular}

\begin{tabular}{ll}
\hline Perangkat K\&I No. 4 & Sistem Basis Data Kriteria dan Indikator CIFOR \\
& McDougall, C., Isbadi, I.R., Santoso, L., Corless, M. dan \\
& Purnomo, H. (ed.) \\
\hline Perangkat K\&I No. 5 & Panduan Penilaian Dasar Kesejahteraan Manusia \\
& Colfer, C.J.P., Brocklesby, M.A., Diaw, C., Etuge, P., Günter, \\
& M., Harwell, E., McDougall, C., Porro, N.M., Porro, R., \\
& Prabhu, R., Salim, A., Sardjono, M.A., Tchikangwa, B., Tiani, \\
& A.M., Wadley, R.L., Wolfel, J. dan Wollenberg, E. \\
\hline Perangkat K\&I No. 6 & Panduan Pendamping Penilaian Dasar Kesejahteraan \\
& Manusia \\
& Colfer, C.J.P, Brocklesby, M.A., Diaw, C., Etuge, P., Günter, \\
& M., Harwell, E., McDougall, C., Porro, N.M., Porro, R., \\
& Prabhu, R., Salim, A., Sardjono, M.A., Tchikangwa, B., Tiani, \\
& A.M., Wadley, R.L., Woelfel, J. dan Wollenberg, E. \\
\hline Perangkat K\&I No. 7 & Panduan Cara Pemberian Skor dan Analisis untuk Menilai \\
& Kesejahteraan Manusia \\
& Salim, A. dan Colfer, C.J.P, dengan McDougall, C. \\
\hline Perangkat K\&I No. 8 & Siapa yang Perlu Dipertimbangkan? Menilai Kesejahteraan \\
& Manusia dalam Pengelolaan Hutan Lestari \\
& Colfer, C.J.P., Prabhu, R., Günter, M., McDougall, C., Porro, \\
& N.M. dan Porro, R. \\
\hline Panduan untuk Menerapkan Analisis Multikriteria dalam \\
Menilai Kriteria dan Indikator \\
Mendoza, G.A., dan Macoun, P. dengan Prabhu, R., Sukadri, \\
D., Purnomo, dan Hartanto, H. \\
\hline
\end{tabular}

Perangkat K\&I No. 10 Metodologi untuk Menilai Indikator Ekologis dalam Pengelolaan Hutan Lestari (Dalam Persiapan) 


\section{DAFTAR ISI}

Panduan Penilaian Kesejahteraan Manusia di Kawasan

Pembalakan Hutan

Panduan Pendamping Penilaian Dasar:

Metode-metode Pelengkap untuk Menilai Kesejahteraan

Manusia

A. IDENTIFIKASI STAKEHOLDER …............................................ 3

1. Pengambilan Sampel Stakeholder ......................................... 3

2. Catpac …........................................................................... 10

B. KEAMANAN AKSES ANTARGENERASI TERHADAP SUMBER DAYA (KAASD) ........................................................ 19

1. Metode Kontinuum Iteratif (MKI) ...................................... 22

2. Pembagian Manfaat di antara Para Stakeholder:

Metode Distribusi Kerikil ....................................................... 26

3. Transek Sejarah Lansekap .................................................... 34

C. HAK DAN KEMAMPUAN UNTUK MENGELOLA HUTAN SECARA BERSAMA DAN ADIL .............................................. 39

1. Penyortiran Kartu Skor ............................................................ 41

2. Metode Kontinuum Iteratif (MKI) ...................................... 50

3. Panduan bagi Peneliti untuk Menilai Partisipasi .................... 52

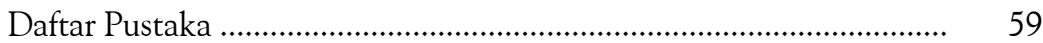




\section{PANDUAN PENILAIAN KESEJAHTERAAN MANUSIA DI KAWASAN PEMBALAKAN HUTAN}

Panduan ini dirancang untuk digunakan oleh individu dan organisasi yang ingin menilai kelestarian kegiatan penebangan hutan untuk diambil kayunya. Pengguna potensial panduan-panduan ini mencakup lembaga-lembaga sertifikasi, pengusaha yang bergerak di bidang perkayuan, badan-badan donor, masyarakat lokal, pemerintah, peneliti, dll. Panduan-panduan ini tidak hanya tepat untuk melakukan satu kali penilaian, tetapi dapat juga digunakan sebagai bagian dari program pemantauan yang dapat mendukung peningkatan kondisi hutan dan juga perbaikan kondisi masyarakat. Kegiatankegiatan CIFOR sebelumnya dan yang lainnya telah menyimpulkan bahwa kesejahteraan masyarakat yang hidup di kawasan di mana pembalakan komersial sedang berlangsung (dan juga pemeliharaan/perbaikan fungsi ekologi) sangat menentukan kelestarian pengelolaan hutan, baik untuk alasan pragmatis atau etis.

Tantangan untuk menilai kesejahteraan manusia secara cepat, mudah dan dapat diandalkan memacu CIFOR untuk memulai suatu studi perbandingan metode-metode ilmu sosial yang sesuai untuk digunakan dalam penilaian seperti ini (lihat Colfer 1997). Panduan-panduan ini telah dikembangkan berdasarkan hasil pengujian metode-metode secara sistematis di Kamerun, Indonesia, dan Brasil, serta kegiatan tambahan di Trinidad, Gabon dan Amerika Serikat. Dalam mengevaluasi pengelolaan hutan lestari, diasumsikan bahwa para penilai akan mendatangi kamp kerja perusahaan kayu dan desa-desa, mengajukan pertanyaan yang tepat tentang masyarakat di kawasan tersebut, dan memeriksa data yang tersedia di perusahaan dan kantor-kantor pemerintah lokal, serta menggunakan metode-metode yang disarankan di sini. 
Panduan penilaian ini didasarkan pada serangkaian kriteria dan indikator (atau $\mathrm{K} \& \mathrm{I})$, yang dikembangkan oleh tim CIFOR di seluruh dunia. K\&I global ini dimaksudkan untuk dipakai sebagai pola dasar untuk melakukan penilaian kelestarian suatu hutan tertentu (termasuk kesejahteraan penduduk yang hidup di dalam dan sekitarnya). Idealnya, set K\&I global ini akan disesuaikan dengan kondisi lokal (lihat CIMAT dan komponen lain Kumpulan Peralatan K\&I CIFOR untuk perangkat adaptasi).

Kami memberikan fokus pada isu-isu sosial kritis yang nyata, dan berasumsi bahwa isu-isu ekologi dan kehutanan konvensional juga akan dibahas dalam penilaian kelestarian suatu hutan tertentu. Kami juga merekomendasikan untuk memasukkan data referensi spasial (ruang), untuk digunakan dalam aplikasi GIS dan untuk memudahkan hubungan dengan data sensus atau data rumah tangga. Dalam rangka memudahkan (kemampuan) para pengguna untuk dapat mengambil keputusan tentang apakah suatu hutan dikelola secara lestari, kami menyarankan serangkaian langkah dan sistem pemberian skor yang dapat dijadikan pengukur isu-isu sosial secara diferensial, berdasarkan pada pengalaman kami sebelumnya.

Penilaian terbaik tentang kesejahteraan manusia biasanya dilakukan oleh ilmuwan sosial yang terlatih. Namun, karena tidak semua kelompok yang berkepentingan untuk penilaian seperti ini mempunyai akses untuk mendapatkan tenaga ahli seperti ini, maka kami telah menerbitkan dua panduan yang terpisah. Pertama, Panduan Penilaian Dasar (PPD), menyediakan sebuah pendekatan 'buku resep' untuk melakukan penilaian. Panduan ini tidak mencerminkan idealisme kami. Namun, kami percaya panduan ini dapat memberikan petunjuk dalam kasus-kasus di mana penilai bukan ilmuwan sosial yang kompeten. Setiap penilai akan membutuhkan ketrampilan dalam hal-hal berikut: 
- Kemampuan dan motivasi untuk berkomunikasi dengan sikap terbuka dan menyenangkan dengan stakeholder yang sangat beragam, termasuk terutama masyarakat lokal dan para karyawan;

- Akses untuk mendapatkan penerjemah sesuai kebutuhan;

- Kesabaran untuk mendorong dan memperoleh informasi dari kelompok yang kurang terlibat, seperti wanita, orang kecil, golongan masyarakat berkasta rendah;

- Kemampuan untuk menimbang informasi dengan sikap yang tidak bias, terutama menghindari peran pembela untuk satu kelompok stakeholder tertentu;

- Kesadaran akan perbedaan budaya dan keingintahuan tentang sistem pengelolaan lokal; dan

- Waktu yang cukup di lapangan untuk melakukan penilaian (idealnya paling sedikit sebulan).

Ada lima langkah utama dalam PPD:

1. Identifikasi stakeholder yang relevan;

2. Penilaian keamanan akses antargenerasi terhadap sumber daya;

3. Penilaian hak dan tanggung jawab untuk mengelola hutan secara bersama-sama;

4. Penilaian terhadap kesehatan hutan (forest health), para pengguna hutan dan budayanya; dan

5. Metode ringkas pemberian skor.

Pembahasan berikut tentang masing-masing metode menyediakan saransaran pengambilan sampel dan bahan-bahan yang dibutuhkan. Upaya yang terus-menerus perlu dilakukan untuk mencerminkan keragaman stakeholder di kawasan itu, dengan kepentingan, kondisi dan masalah masing-masing. 
Kelompok stakeholder ini mencakup wanita, kelompok etnis yang tersisih, kelompok umur yang kurang terwakili, kaum miskin, dan kelompok lain yang biasanya terabaikan. Penting juga untuk dipertimbangkan isu-isu mengenai perwakilan, dan pastikan bahwa Anda akan mendapatkan pandangan yang seluas mungkin dari keragaman para penggunanya. Manfaat penggunaan bahasa lokal sebanyak mungkin sangat penting. Penilaian akan lebih mudah dan lebih cepat jika Anda dapat menggunakan komputer laptop. Setiap metode memerlukan bahan-bahan tertentu, tetapi umumnya tidak mahal (kertas, pena, kerikil atau kacang, lembaran kertas berukuran besar, pena berwarna, peta, dll.).

Bacalah panduan secara keseluruhan sebelum memulai penilaian, karena langkah-langkah awal akan sangat membantu langkah-langkah selanjutnya, jika Anda peka dan sudah siap.

Panduan Pendamping Penilaian Dasar (PPPD) menyediakan sejumlah metode tambahan yang kami temukan sangat berguna. Walaupun metode-metode ini dipandang sangat berharga oleh ilmuwan sosial dalam uji lapang, metode ini telah dipisahkan dari 'buku resep' karena bertumpang tindih dengan metode lain dalam PPD atau karena kesulitannya bagi ilmuwan nonsosial. Dapat dimengerti bahwa ilmuwan sosial yang berkualifikasi mungkin akan lebih memilih metode yang dipertimbangkan cocok untuk situasi tertentu; namun demikian, keahlian mereka mungkin akan sia-sia jika mereka diminta mengikuti prosedur yang diperintahkan seperti yang diusulkan dalam PPD. Pendekatan-pendekatan yang disarankan dalam PPD memberikan cukup banyak kesempatan untuk menggunakan pertimbangan profesional. Tujuan kami adalah memberikan kesempatan kepada ilmuwan sosial terlatih untuk memeriksa semua metode yang dijelaskan dan memilih yang paling sesuai untuk kawasan yang sedang dinilai. 
Perangkat K\&I ketiga yang sangat erat hubungannya adalah Panduan Cara Pemberian Skor dan Analisis untuk Menilai Kesejahteraan Manusia. Perangkat ini menyajikan cara-cara pemberian skor dan membantu dalam membuat pertimbangan-pertimbangan kualitatif secara sistematis, sehingga semua K\&I dapat dinilai dan dievaluasi. Bagian yang membahas analisis hanya memerlukan sedikit ketrampilan komputer, dan secara hati-hati memandu pembaca melakukan tahap-tahap yang diperlukan untuk menganalisis data kuantitatif (misalnya, dari metode distribusi kerikil atau penyortiran kartu), mulai dari memasukkan data awal melalui prosedur statistik yang mungkin diinginkan oleh para pengguna. Penjelasan untuk memasukkan data awal ini menggunakan lembar isian Excel dan SPSS. 


\section{PANDUAN PENDAMPING PENILAIAN DASAR: METODE-METODE PELENGKAP UNTUK MENILAI KESEJAHTERAAN MANUSIA}

Panduan pendamping ini ditulis sebagai pengakuan atas tingginya keanekaragaman ciri-ciri untuk menilai kesejahteraan manusia dalam berbagai lingkungan yang berbeda. Beberapa metode yang disediakan dalam Panduan Penilaian Dasar, kemungkinan akan dianggap kurang untuk beberapa lokasi tertentu. Oleh karena itu, kami menyediakan bagi Anda beberapa metode yang dapat melengkapi dan/atau menggantikan metode yang memiliki kekurangan tersebut.

Kami juga mengakui adanya berbagai kualifikasi dan pengalaman yang berbeda yang akan dimiliki oleh para penilai dalam melakukan penilaian. Metode-metode berikut ini telah diuji di beberapa lokasi di Kamerun, Indonesia, dan Brasil. Metode-metode ini dipandang sangat bermanfaat, dan mungkin lebih sesuai dalam konteks-konteks khusus, atau lebih menarik bagi para pengguna yang lebih terlatih atau berpengalaman dalam ilmu sosial, daripada metode-metode yang diberikan dalam PPD. Metode-metode dalam Panduan Pendamping Penilaian Dasar mungkin juga memberikan andil dalam melakukan penilaian yang lebih menyeluruh, jika waktu dan sumber dayanya tersedia.

Proses pemberian skor tetap sama seperti dalam PPD:

- Menggunakan lembar isian induk K\&I (lihat Panduan Cara Pemberian Skor dan Analisis untuk Menilai Kesejahteraan Manusia);

- Mengumpulkan bukti/kasus-kasus yang berkaitan dengan K\&I, dan 
- Menetapkan skor, berdasarkan Panduan Cara Pemberian Skor dan Analisis untuk Menilai Kesejahteraan Manusia, skor 1 = paling tidak lestari dan skor $10=$ paling lestari. 


\section{A Identifikasi Stakeholder}

Di sini kami menawarkan dua pilihan untuk membantu para penilai mengidentifikasi stakeholder yang relevan: matriks Wollenberg (1997) untuk memastikan keterwakilan berbagai masyarakat lokal dan paket analisis jaringan syaraf yang disebut CatPac. Metode pertama berfungsi sebagai 'penyaring', untuk membantu memastikan bahwa berbagai stakeholder lokal yang penting diakui dan diketahui. Metode kedua memerlukan piranti lunak komputer dan ketrampilan mengoperasikannya.

\section{PENGAMBILAN SAMPEL STAKEHOLDER}

[disadur dari Wollenberg 1997]

Kami telah menemukan bahwa dalam suatu kelompok stakeholder mana pun yang ciri-cirinya jelas, umumnya variasi di antara anggota-anggota kelompok cukup banyak. Untuk memahami keterwakilan suatu subkelompok stakeholder, kami memerlukan cara-cara untuk mengetahui perbedaan-perbedaan yang ada di antara anggota-anggota suatu kelompok stakeholder, sehingga perbedaan-perbedaan ini dapat diketahui dengan tepat. Anda dapat menggunakan beberapa informasi untuk membantu memilih sebuah sampel anggota-anggota stakeholder yang tepat - menunjukkan kisaran persepsi stakeholder secara keseluruhan, yang penting untuk melakukan penilaian yang baik.

Setelah kelompok-kelompok stakeholder yang penting diidentifikasi, sebuah matriks sampel merupakan suatu alat yang dapat digunakan untuk mengembangkan gambaran yang lebih rinci tentang perbedaan-perbedaan 
di antara anggota suatu kelompok stakeholder. Matriks dapat digunakan untuk berbagai tujuan. Peran yang terpenting adalah untuk membantu menjawab pertanyaan: perbedaan-perbedaan apa saja yang ada di antara para anggota suatu kelompok stakeholder? Perhatikan bahwa tingkat analisis ini dapat menghabiskan waktu, dan mungkin tidak perlu atau tidak tepat untuk setiap kelompok stakeholder. Kebutuhan untuk menyesuaikan metode ini harus seimbang dengan biaya untuk memperoleh informasi. Metode ini dapat menjadi sebuah kesempatan untuk memperoleh informasi kualitatif yang konseptual dan berharga.

\section{PENGGUNAAN MATRIKS PENGAMBILAN SAMPEL}

1. Pilih suatu kelompok stakeholder.

2. Pilah atau pisahkan kelompok stakeholder menurut hal-hal yang membedakannya dalam masyarakat lokal. Sumber-sumber perbedaan ini mungkin mencakup umur, jender, agama dan status ekonomi (lihat judul baris dalam matriks di bawah ini). Dalam konteks inisiatif lainnya, pemilahan kelompok stakeholder lainnya mungkin dapat digunakan. Misalnya, dalam tabel di bawah, kelompok-kelompok dipilah menurut hubungannya dengan HPH lokal. Semua kategori-kategori subkelompok mungkin tidak diterapkan oleh setiap kelompok stakeholder.

3. Untuk setiap subkelompok dari kelompok stakeholder, tanyakan pertanyaan-pertanyaan penilaian (lihat judul kolom di bawah). Anda dapat memilih tipe apa saja atau jumlah pertanyaan penilaian yang sesuai tergantung masalahnya. Pertanyaan-pertanyaan ini mungkin mencerminkan aspek-aspek keterlibatan stakeholder yang berbeda dalam pengelolaan atau dampak pengelolaan terhadap mereka. Porro dan Porro (1998) mengusulkan tidak lebih dari 12 pertanyaan, berdasarkan 
pengalaman mereka dengan metode ini di Brasil. Untuk menyederhanakan analisis, pertanyaan-pertanyaan dapat diutarakan secara konsisten sehingga semua jawaban 'ya' menunjukkan akhir dari satu rangkaian penilaian (misalnya, lestari) sementara semua jawaban 'tidak' menunjukkan kualitas sebaliknya terhadap penilaian ini (misalnya, tidak lestari). ${ }^{1}$ Alternatif lainnya adalah memberikan skor 1-10, yang konsisten dengan metode-metode lain dalam panduan ini.

4. Kelompok-kelompok yang kebanyakan menjawab 'ya' atau 'tidak' atau skornya tinggi atau rendah mungkin menunjukkan tanda-tanda bahwa ada subkelompok-subkelompok penting lainnya yang dipertimbangkan lebih lanjut.

Tiga contoh berikut ini menggunakan sebuah desa hipotesis di Kalimantan Timur:

1 Kami mengakui bahwa jawaban-jawaban terhadap pertanyaan-pertanyaan ini mungkin rumit, untuk memperoleh jawaban dari contoh-contoh atau kasus-kasus, dan jawaban 'ya' dan 'tidak' mungkin dalam beberapa kasus terlalu banyak disederhanakan. 


\section{KELOMPOK STAKEHOLDER: PENDUDUK INDIJENUS DI SEKITAR DAERAH OPERASI HPH}

\section{A.PENILAIANMANFAATHUTAN}

$$
1=\text { rendah, } 10=\text { tinggi }
$$

\begin{tabular}{|c|c|c|c|c|c|}
\hline $\begin{array}{l}\text { Kategori-kategori } \\
\text { penduduk dalam } \\
\text { kelompok } \\
\text { stakeholder }\end{array}$ & $\begin{array}{c}\text { Tuntutan hak } \\
\text { terhadap lahan } \\
\text { atau hasil- } \\
\text { hasil hutan? }\end{array}$ & $\begin{array}{l}\text { Penggunaan } \\
\text { hasil-hasil } \\
\text { hutan? }\end{array}$ & $\begin{array}{c}\text { Mendapat penghasilan } \\
\text { dari kegiatan yang ber- } \\
\text { kaitan dengan hutan } \\
\text { (misalnya, HPH) }\end{array}$ & $\begin{array}{c}\text { Mata } \\
\text { pencaharian } \\
\text { utama dari lahan } \\
\text { hutan/hutan? }\end{array}$ & $\begin{array}{c}\text { Manfaat } \\
\text { keuntungan } \\
\text { budaya dikaitkan } \\
\text { dengan hutan }\end{array}$ \\
\hline $\begin{array}{l}\text { Kelompok Umur } \\
\text { Tua } \\
\text { Dewasa } \\
\text { Muda }\end{array}$ & $\begin{array}{c}5 \\
10 \\
9\end{array}$ & $\begin{array}{c}8 \\
10 \\
10\end{array}$ & $\begin{array}{l}1 \\
3 \\
1\end{array}$ & $\begin{array}{l}5 \\
8 \\
8\end{array}$ & $\begin{array}{l}10 \\
7 \\
5\end{array}$ \\
\hline $\begin{array}{l}\text { Jender } \\
\text { Wanita } \\
\text { Pria }\end{array}$ & $\begin{array}{c}7 \\
10\end{array}$ & $\begin{array}{c}8 \\
10\end{array}$ & $\begin{array}{l}2 \\
5\end{array}$ & $\begin{array}{c}5 \\
10\end{array}$ & $\begin{array}{l}7 \\
7\end{array}$ \\
\hline $\begin{array}{l}\text { Kemakmuran } \\
\text { Rendah } \\
\text { Rata-rata } \\
\text { Lebih baik }\end{array}$ & $\begin{array}{c}5 \\
10 \\
8\end{array}$ & $\begin{array}{c}10 \\
8 \\
5\end{array}$ & $\begin{array}{l}1 \\
2 \\
5\end{array}$ & $\begin{array}{l}7 \\
9 \\
5\end{array}$ & $\begin{array}{l}5 \\
7 \\
8\end{array}$ \\
\hline $\begin{array}{l}\text { Status Sosial } \\
\quad \text { Tinggi } \\
\text { Rata-rata } \\
\text { Rendah }\end{array}$ & $\begin{array}{l}7 \\
7 \\
7\end{array}$ & $\begin{array}{c}8 \\
8 \\
10\end{array}$ & $\begin{array}{l}5 \\
2 \\
1\end{array}$ & $\begin{array}{l}7 \\
9 \\
7\end{array}$ & $\begin{array}{l}8 \\
7 \\
5\end{array}$ \\
\hline $\begin{array}{l}\text { Waktu menetap } \\
\text { Jangka panjang } \\
\text { Pendatang baru }\end{array}$ & $\begin{array}{l}9 \\
4\end{array}$ & $\begin{array}{l}9 \\
6\end{array}$ & $\begin{array}{l}5 \\
1\end{array}$ & $\begin{array}{l}9 \\
6\end{array}$ & $\begin{array}{l}8 \\
3\end{array}$ \\
\hline $\begin{array}{l}\text { Kelompok etnis } \\
\text { Punan } \\
\text { Merap }\end{array}$ & $\begin{array}{c}5 \\
10\end{array}$ & $\begin{array}{c}10 \\
9\end{array}$ & $\begin{array}{l}1 \\
3\end{array}$ & $\begin{array}{c}10 \\
9\end{array}$ & $\begin{array}{l}7 \\
7\end{array}$ \\
\hline $\begin{array}{l}\text { Kelompok agama } \\
\text { Protestan } \\
\text { Katolik }\end{array}$ & $\begin{array}{l}7 \\
7\end{array}$ & $\begin{array}{l}9 \\
9\end{array}$ & $\begin{array}{l}3 \\
3\end{array}$ & $\begin{array}{l}6 \\
9\end{array}$ & $\begin{array}{l}7 \\
7\end{array}$ \\
\hline $\begin{array}{l}\text { Hubungan dengan } \\
\text { HPH } \\
\text { Pengelolaan } \\
\text { Pekerja } \\
\text { Penganggur }\end{array}$ & $\begin{array}{l}5 \\
7 \\
9\end{array}$ & $\begin{array}{l}3 \\
9 \\
9\end{array}$ & $\begin{array}{c}10 \\
8 \\
1\end{array}$ & $\begin{array}{l}1 \\
5 \\
9\end{array}$ & $\begin{array}{l}3 \\
5 \\
9\end{array}$ \\
\hline
\end{tabular}




\section{B. PENILAIAN SUARA}

\section{$1=$ sangat benar, $10=$ tidak benar}

\begin{tabular}{|c|c|c|c|c|c|}
\hline $\begin{array}{c}\text { Kategori-kategori } \\
\text { penduduk dalam } \\
\text { kelompok } \\
\text { stakeholder }\end{array}$ & $\begin{array}{l}\text { Tidak bebas } \\
\text { dapat menun- } \\
\text { jukkan persepsi } \\
\text { kepada HPH? }\end{array}$ & $\begin{array}{l}\text { Apakah tidak } \\
\text { menerima } \\
\text { informasi } \\
\text { dari HPH? }\end{array}$ & $\begin{array}{c}\text { Tidak } \\
\text { berkonsultasi } \\
\text { dengan } \\
\text { HPH? }\end{array}$ & $\begin{array}{c}\text { Apakah tidak umum } \\
\text { dengan rencana-rencana } \\
\text { pengelolaan hutan yang } \\
\text { mungkin mempernga- } \\
\text { ruhi mereka? }\end{array}$ & $\begin{array}{c}\text { Apakah tidak } \\
\text { diijinkan untuk } \\
\text { memantau kegiatan- } \\
\text { kegiatan hutan }\end{array}$ \\
\hline $\begin{array}{l}\text { Kelompok umur } \\
\text { Tua } \\
\text { Dewasa } \\
\text { Muda }\end{array}$ & $\begin{array}{l}7 \\
5 \\
2\end{array}$ & $\begin{array}{l}6 \\
5 \\
1\end{array}$ & $\begin{array}{l}5 \\
4 \\
1\end{array}$ & $\begin{array}{l}6 \\
5 \\
3\end{array}$ & $\begin{array}{l}2 \\
3 \\
1\end{array}$ \\
\hline $\begin{array}{l}\text { Jender } \\
\text { Wanita } \\
\text { Pria }\end{array}$ & $\begin{array}{l}1 \\
8\end{array}$ & $\begin{array}{l}1 \\
8\end{array}$ & $\begin{array}{l}1 \\
6\end{array}$ & $\begin{array}{l}2 \\
5\end{array}$ & $\begin{array}{l}2 \\
2\end{array}$ \\
\hline $\begin{array}{l}\text { Kemakmuran } \\
\text { Rendah } \\
\text { Rata-rata } \\
\text { Lebih baik }\end{array}$ & $\begin{array}{l}1 \\
5 \\
8\end{array}$ & $\begin{array}{l}3 \\
5 \\
8\end{array}$ & $\begin{array}{l}1 \\
2 \\
3\end{array}$ & $\begin{array}{l}3 \\
5 \\
7\end{array}$ & $\begin{array}{l}2 \\
2 \\
2\end{array}$ \\
\hline $\begin{array}{l}\text { Status Sosial } \\
\quad \text { Tinggi } \\
\text { Rata-rata } \\
\text { Rendah }\end{array}$ & $\begin{array}{l}1 \\
5 \\
8\end{array}$ & $\begin{array}{l}9 \\
5 \\
3\end{array}$ & $\begin{array}{l}5 \\
2 \\
1\end{array}$ & $\begin{array}{l}8 \\
5 \\
2\end{array}$ & $\begin{array}{l}4 \\
2 \\
2\end{array}$ \\
\hline $\begin{array}{l}\text { Waktu menetap } \\
\text { Jangka panjang } \\
\text { Pendatang baru }\end{array}$ & $\begin{array}{l}2 \\
7\end{array}$ & $\begin{array}{l}6 \\
2\end{array}$ & $\begin{array}{l}4 \\
1\end{array}$ & $\begin{array}{l}5 \\
3\end{array}$ & $\begin{array}{l}3 \\
2\end{array}$ \\
\hline $\begin{array}{l}\text { Kelompok etnis } \\
\text { Punan } \\
\text { Merap }\end{array}$ & $\begin{array}{l}1 \\
6\end{array}$ & $\begin{array}{l}1 \\
6\end{array}$ & $\begin{array}{l}1 \\
4\end{array}$ & $\begin{array}{l}2 \\
5\end{array}$ & $\begin{array}{l}1 \\
4\end{array}$ \\
\hline $\begin{array}{l}\text { Kelompok agama } \\
\text { Protestan } \\
\text { Katolik }\end{array}$ & $\begin{array}{l}2 \\
5\end{array}$ & $\begin{array}{l}2 \\
5\end{array}$ & $\begin{array}{l}1 \\
2\end{array}$ & $\begin{array}{l}3 \\
4\end{array}$ & $\begin{array}{l}1 \\
2\end{array}$ \\
\hline $\begin{array}{l}\text { Hubungan dengan } \\
\text { HPH } \\
\quad \text { Pengelolaan } \\
\quad \text { Pekerja } \\
\quad \text { Penganggur }\end{array}$ & $\begin{array}{l}9 \\
7 \\
2\end{array}$ & $\begin{array}{l}9 \\
8 \\
2\end{array}$ & $\begin{array}{l}9 \\
5 \\
2\end{array}$ & $\begin{array}{l}9 \\
7 \\
3\end{array}$ & $\begin{array}{l}6 \\
6 \\
2\end{array}$ \\
\hline
\end{tabular}


Anda dapat menyebutkan kriteria positif (misalnya, memberi andil untuk kelestarian) atau negatif (misalnya, memberi andil untuk ketidaklestarian), sesuai tujuan penilaian. Dalam banyak contoh, hal-hal negatif akan lebih membantu sebagai cara-cara penilaian langsung. Oleh sebab itu kami telah menyusun tabel penilaian suara menggunakan pernyataan-pernyataan negatif yang mencerminkan bagaimana penduduk tidak memiliki suara dalam pengelolaan hutan. Misalnya, skor yang secara konsisten rendah di antara wanita menunjukkan rendahnya masukan yang mereka berikan dalam pengambilan keputusan dibandingkan dengan masukan dari perusahaan HPH lokal.

Di bawah ini ada satu contoh matriks kriteria dan indikator yang berkaitan dengan peranan penduduk dalam pengelolaan hutan. Dalam tabel ini skor tinggi menunjukkan bahwa subkelompok bertindak untuk mengelola hutan secara lestari. Skor rendah menunjukkan lemahnya peranan mereka dalam pengelolaan hutan. Keanekaragaman skor yang cukup tinggi dalam tabel ini mencerminkan beragamnya peran stakeholder dalam pengelolaan hutan. Misalnya, anggota-anggota masyarakat yang lebih tua di sebuah desa mungkin memberi andil sedikit dalam hal memberikan masukan untuk pengelolaan hutan, tetapi andil mereka besar sekali dalam pengambilan keputusan di desa karena status mereka sebagai yang dituakan. 


\section{TINDAKAN PENDUDUK MEMPENGARUHI PENGELOLAAN HUTAN}

\section{$1=$ tidak terlalu sering $10=$ sangat sering}

\begin{tabular}{|c|c|c|c|c|}
\hline $\begin{array}{c}\text { Kategori-kategori } \\
\text { penduduk dalam } \\
\text { kelompok } \\
\text { stakeholder }\end{array}$ & $\begin{array}{l}\text { Mematuhi dan } \\
\text { merawat batas- } \\
\text { batas hutan } \\
\text { desa? }\end{array}$ & $\begin{array}{l}\text { Menyediakan dana yang } \\
\text { nyata untuk pengelolaan } \\
\text { hutan? (pekerja, informasi, } \\
\text { penanaman ulang) }\end{array}$ & $\begin{array}{c}\text { Kemampuan } \\
\text { memantau kualitas } \\
\text { hutan? }\end{array}$ & $\begin{array}{l}\text { Masukan yang } \\
\text { efektif terhadap } \\
\text { pembuatan } \\
\text { keputusan desa }\end{array}$ \\
\hline $\begin{array}{l}\text { Kelompok umur } \\
\text { Tua } \\
\text { Dewasa } \\
\text { Muda }\end{array}$ & $\begin{array}{l}9 \\
8 \\
5\end{array}$ & $\begin{array}{l}5 \\
7 \\
7\end{array}$ & $\begin{array}{l}5 \\
6 \\
8\end{array}$ & $\begin{array}{l}9 \\
8 \\
4\end{array}$ \\
\hline $\begin{array}{l}\text { Jender } \\
\text { Wanita } \\
\text { Pria }\end{array}$ & $\begin{array}{l}8 \\
7\end{array}$ & $\begin{array}{l}5 \\
8\end{array}$ & $\begin{array}{l}5 \\
8\end{array}$ & $\begin{array}{l}3 \\
8\end{array}$ \\
\hline $\begin{array}{l}\text { Kemakmuran } \\
\text { Rendah } \\
\text { Rata-rata } \\
\text { Lebih baik }\end{array}$ & $\begin{array}{l}7 \\
7 \\
4\end{array}$ & $\begin{array}{l}7 \\
6 \\
4\end{array}$ & $\begin{array}{l}5 \\
6 \\
4\end{array}$ & $\begin{array}{l}3 \\
5 \\
8\end{array}$ \\
\hline $\begin{array}{l}\text { Status Sosial } \\
\text { Tinggi } \\
\text { Rata-rata } \\
\text { Rendah }\end{array}$ & $\begin{array}{l}6 \\
7 \\
7\end{array}$ & $\begin{array}{l}6 \\
7 \\
7\end{array}$ & $\begin{array}{l}6 \\
7 \\
5\end{array}$ & $\begin{array}{c}10 \\
5 \\
2\end{array}$ \\
\hline $\begin{array}{l}\text { Waktu menetap } \\
\text { Jangka panjang } \\
\text { Pendatang baru }\end{array}$ & $\begin{array}{l}7 \\
3\end{array}$ & $\begin{array}{l}7 \\
4\end{array}$ & $\begin{array}{l}8 \\
3\end{array}$ & $\begin{array}{l}8 \\
4\end{array}$ \\
\hline $\begin{array}{l}\text { Kelompok etnis } \\
\text { Punan } \\
\text { Merap }\end{array}$ & $\begin{array}{l}5 \\
9\end{array}$ & $\begin{array}{l}6 \\
8\end{array}$ & $\begin{array}{l}9 \\
6\end{array}$ & $\begin{array}{l}5 \\
9\end{array}$ \\
\hline $\begin{array}{l}\text { Kelompok agama } \\
\text { Protestan } \\
\text { Katolik }\end{array}$ & $\begin{array}{l}6 \\
8\end{array}$ & $\begin{array}{l}7 \\
8\end{array}$ & $\begin{array}{l}8 \\
6\end{array}$ & $\begin{array}{l}6 \\
7\end{array}$ \\
\hline $\begin{array}{l}\text { Hubungan dengan } \\
\text { HPH } \\
\text { Pengelolaan } \\
\text { Pekerja } \\
\text { Penganggur }\end{array}$ & $\begin{array}{l}3 \\
3 \\
7\end{array}$ & $\begin{array}{l}4 \\
5 \\
6\end{array}$ & $\begin{array}{l}3 \\
7 \\
6\end{array}$ & $\begin{array}{l}7 \\
5 \\
7\end{array}$ \\
\hline
\end{tabular}


Walaupun hasil-hasil dari metode ini awalnya dirancang untuk membantu mengidentifikasi subkelompok pengelola hutan yang penting, diskusi informal yang berlangsung bersamaan dengan wawancara ini akan menyediakan bukti-bukti dan kasus-kasus yang sangat berarti untuk digunakan dalam pemberian skor K\&I. Informasi seperti ini harus diperhatikan dan diberi skor dalam lembar isian induk K\&I.

\section{CATPAC}

Metode yang menggunakan sistem komputer ini disebut 'paket analisis jaringan syaraf', diperkenalkan kepada kami oleh Joseph Woelfel (salah seorang penciptanya). Metode ini mampu menganalisis pembicaraan penduduk secara cepat (dalam bentuk teks), untuk mengenali kumpulan konsep. Metode ini telah digunakan dalam menilai pilihan konsumen dan menargetkan usaha-usaha periklanan secara tepat. Dengan mengidentifikasi konsep-konsep yang membentuk kelompok-kelompok bahasa dan kemampuan kognitif dalam pikiran penduduk yang terlibat dalam pengelolaan hutan, akhirnya kami akan mampu meningkatkan kualitas pengelolaan. Pada tahap ini, kami menggunakan CatPac untuk menjelaskan perbedaan yang ada di antara kelompok-kelompok stakeholder.

\section{TUJUAN}

- Untuk mengetahui perasaan kedekatan yang dimiliki penduduk terhadap hutan;

- Untuk mengetahui tingkat integrasi antara budaya dengan hutan di antara kelompok-kelompok di suatu kawasan; dan 
- Untuk menetapkan apakah penduduk memiliki 'etika konservasi' atau tidak.

Isu-isu ini yang muncul dalam pengujian kriteria dan indikator kami sebelumnya dianggap penting, sebagai dimensi-dimensi yang potensial untuk menentukan 'siapa yang perlu dipertimbangkan' dalam pengelolaan hutan lestari (bandingkan dengan Colfer 1999, dan PPD). Kedekatan dengan hutan dan integrasi budaya dan hutan yang kuat mempunyai implikasi terhadap kesejahteraan manusia jika hutan menjadi hancur. Adanya etika konservasi mungkin memudahkan pengelolaan hutan lestari.

\section{PESERTA}

Tentukan 3-5 kelompok stakeholder yang penting dan berbeda untuk studi ini. Pilih jumlah peserta pria dan wanita yang seimbang (jika mungkin) dalam 3-5 kategori stakeholder ini. Wawancarai paling sedikit 12-15 orang untuk masing-masing kategori (misalnya, 12-15 peserta x dua jender x 3-5 kategori). ${ }^{2}$ Semakin besar perbedaan dalam kelompok stakeholder, perbedaan kognitif di antaranya lebih jelas, dan variasi dalam hal integrasi antara hutan dan budaya, serta perasaan kedekatan terhadap hutan akan lebih jelas dan tercermin dari hasil-hasil yang diperoleh.

2 Kami tidak mencari perwakilan yang seimbang di sini, tetapi cukup memahami keanekaragaman konsepsi manusia tentang ciri-ciri hutan yang sedang dinilai. 


\section{BAHAN}

- sebuah alat perekam;

- sebuah komputer yang dapat menjalankan program CatPac; dan

- program CatPac dengan panduan CatPac atau dengan petunjuk-petunjuk dalam Panduan Cara Pemberian Skor dan Analisis untuk Menilai Kesejahteraan Manusia.

\section{METODE}

Metode ini memeriksa kelompok konsep-konsep yang digunakan bersama oleh penduduk dalam pembicaraan mereka, memberikan pengertianpengertian tentang cara-cara penduduk memandang hutan di sekitar mereka.

Pilih satu pertanyaan terbuka mengenai hubungan penduduk terhadap hutan di kawasan mereka. Beberapa pertanyaan yang telah kami gunakan antara lain:

- 'Apa arti hutan bagi Anda?' ('Pour toi la forêt c'est quoi?', Tchikangwa dkk. 1998);

- 'Apa kepentingan hutan dalam kehidupan pribadi Anda?' ('Quelle est l'importance de la forêt dans ta propre vie?', Tiani dkk. 1997);

- 'Apakah arti hutan sekitar desa ini bagi Anda?' (Brocklesby dkk. 1997).

Penggunaan bahasa daerah sangat penting untuk metode ini, karena konsepkonsep hutan yang penting mungkin tidak dapat diterjemahkan ke dalam bahasa nasional. Catat pertanyaan yang Anda tanyakan dan informasi demografi yang Anda butuhkan dalam analisis (umur, jenis kelamin, pekerjaan, kelompok etnis, dll). Kemudian rekam jawaban atas pertanyaan terbuka Anda. Idealnya Anda tidak berbicara setelah pertanyaan pertama, 
kecuali untuk menanggapi dengan suara seperti 'mmhmm' atau 'ada yang lainnya?'. Bila Anda terlibat dalam percakapan normal, metode ini tidak akan berhasil.

Lakukan wawancara dalam bahasa daerah, dengan pertolongan sebuah alat perekam $^{3}$ (berbeda dengan apa yang telah kami lakukan) dan, bila perlu, dengan bantuan seorang penerjemah. Penerjemah harus berbeda jenis kelamin dengan peneliti, untuk meningkatkan akses terhadap bagian-bagian populasi yang lebih beragam. Pastikan bahwa para peserta tahu bahwa Anda merekam jawaban-jawaban mereka dan mereka menyetujuinya. Ini penting dari segi etika.

Waktu wawancara yang pendek antara 2-5 menit cukup memuaskan, dan ada beberapa keuntungan untuk menjaga agar wawancara berlangsung dalam jangka waktu yang sama (sehingga penduduk yang lebih banyak bicara bertele-tele tidak mendominasi hasil keseluruhan). Masalah lain yang serius dengan wawancara yang lama berkaitan dengan waktu yang lama untuk mengetik teks, karena analisis dengan komputer bisa dilakukan dengan cepat.

\section{WAKTU YANG DIPERLUKAN}

Tiani dkk. (1997) melaporkan bahwa mereka dapat merekam sepuluh wawancara dalam 35 menit, menghabiskan waktu 30 menit untuk menerjemah. Sesudah wawancara direkam dan dimasukkan ke dalam komputer, analisis datanya hanya memerlukan beberapa detik.

3 Beberapa peneliti menemukan bahwa penduduk lokal takut terhadap alat perekam (Tiani dkk. 1997 dan Porro dan Porro 1998). Dalam hal ini, Anda dapat menuliskan secara hatihati, kata demi kata dalam percakapan mereka. 
Colfer dan dua asistennya menyelesaikan satu studi CatPac, dari awal hingga selesai, dalam satu hari di Kamerun (November 1996).

\section{ANALISIS DAN PEMBERIAN SKOR ${ }^{4}$}

Bagi jawaban-jawaban dalam kategori-kategori yang ingin Anda gunakan sebagai dasar analisis (pria/wanita; kelompok-kelompok etnis yang berbeda, pekerja, dll.). Masukkan hasil wawancara kata demi kata dalam sebuah program olah kata di komputer. Colfer cukup menuliskan hasil wawancara dari masing-masing kelompok stakeholder dalam file-file yang terpisah (memotong dan menempelkan kembali, dengan rujukan rekaman naskah yang dicetak, ketika kategori-kategori baru akan dianalisis).

Untuk sebagian peneliti, format komputer CatPac adalah sederhana. ${ }^{5}$ Ketik teks dari masing-masing peserta, diikuti dengan 'enter' dan ' -1 ' pada permulaan baris baru. Inilah caranya komputer mengetahui adanya peserta baru. Simpan file sebagai file 'text only' ('.txt').

Kembangkan dan cantumkan kode-kode untuk data demografi peserta (misalnya, jenis kelamin, kelompok etnis, kelompok stakeholder, dll., yang nanti akan Anda pilah-pilah menurut pendapatnya). Buat daftar untuk arti dari kode-kode tersebut. Salim mengusulkan memberikan kode, misalnya, 'wn' untuk wanita, 'u' untuk umur, di depan masing-masing teks wawancara yang dimasukkan dalam file komputer, dan kemudian memasukkan kode-

4 Panduan tambahan tersedia dalam Panduan Cara Pemberian Skor dan Analisis untuk Menilai Kesejahtaraan Manusia.

5 Sebaliknya Brocklesby dkk. (1997) menganggap 'tidak cepat dan juga tidak sederhana' untuk meringkas masalah-masalah yang dialami oleh beberapa pihak kolaborator dalam menggunakan metode ini. 
kode tersebut dalam file tersendiri (dijelaskan di bawah) sehingga data tersebut bukan merupakan bagian dari data yang dianalisis. Ini masih perlu dipotong dan ditempelkan kembali. Program CatPac tidak memiliki mekanisme yang memudahkan penyortiran.

Kembangkan daftar kata-kata yang muncul dalam teks dari wawancara Anda terutama yang mempunyai arti tata bahasa (dalam bahasa daerah), dan tidak menambah pengertian konsep-konsep yang berkaitan dengan hutan secara berarti. Kata-kata ini akan dibutuhkan untuk file 'tersendiri' dalam program CatPac. Pengelompokkan kata-kata seperti ‘adalah' dan 'dia' secara khusus tidak membantu usaha kami untuk memahami interaksi-interaksi antara manusia dengan hutan. Contoh-contoh istilah mencakup kata ganti (kecuali 'saya'), kata sifat seperti 'sangat', banyak', 'paling' membantu katakata kerja seperti 'dapat'. File 'default.exc' pada program CatPac Anda menunjukkan bahwa bahasa Inggris tidak digunakan dalam program asli. Anda dapat menampilkan file ini dan mulai menerjemahkan kata-kata dalam bahasa Inggris ke dalam bahasa yang relevan, walaupun mungkin banyak yang tidak dapat diterjemahkan dan kemungkinan Anda akan mulai dengan bahasa lain dalam bahasa daerah yang tidak ada dalam bahasa Inggris. Kemudian Anda dapat menyimpan file 'default.exc' yang telah direvisi dengan sebuah nama baru (misalnya, Perancis.exc). Kemungkinan Anda perlu mengeluarkan beberapa huruf dan simbol yang tidak sesuai yang mungkin akan muncul dalam analisis awal Anda (kemungkinan ada 'virus' dalam program). Anda juga harus mengeluarkan kode-kode demografi yang telah Anda buat, seperti yang disebutkan di atas.

Lakukan analisis dan interpretasikan. Program ini mengelompokkan konsepkonsep yang muncul bersamaan dan juga dapat membuat plot-plot yang mewakili peta-peta kognitif. Program ini didasarkan pada satu tipe kecerdasan 
buatan yang disebut 'analisis jaringan syaraf'. Hasil sederhananya (disebut sebuah 'dendrogram') ditunjukkan di bawah.

Dendrogram-dendrogram berikut menunjukkan kumpulan konsep-konsep yang mewakili cara-cara penduduk berbicara tentang lingkungan mereka yang berhutan. Karena 'saya' dan 'hutan' bersama-sama dalam satu kelompok set data di Kamerun, secara lokal dirasa ada hubungan yang dekat antara penduduk dan hutan lokal. Kenyataan bahwa konsep-konsep lain yang berkaitan dengan subsistensi (kehidupan, pohon, singkong, kacangkacangan, makanan dll.) muncul dalam jawaban terhadap pertanyaan tentang hutan yang juga menunjukkan hubungan dekat antara budaya penduduk dengan hutan. Satu perbedaan yang menarik antara hasil-hasil di Kamerun dan hasil-hasil di Indonesia adalah pentingnya peranan negara dalam berbagai diskusi tentang hutan di Kamerun.

Kami menempatkan metode ini dalam Panduan Pendamping Penilaian Dasar dan bukan dalam PPD karena dua alasan: Perlunya pertimbangan yang cukup banyak dari penilai dalam menafsir penemuan-penemuan ini; dan reaksireaksi yang berbeda untuk menghadapi program komputer bagi mereka yang melakukan pengujian metode ini. Porro dan Porro (1998) sangat merekomendasikan untuk mengkombinasikan metode ini dengan Metode Kontinuum Iteratif (MKI) dan/atau pengamatan peserta. Metode ini masih tetap menarik karena benar-benar didasarkan pada budaya dan bahasa peserta; bagi sebagian orang analisis komputer mudah dan cepat; dan mudah untuk pengulangan. 


\section{Sampel Dendrogram dari Kawasan Lindung Dja}

(Tchikangwa dkk. 1998)

\begin{tabular}{|lrlr|}
\hline TOTAL KATA-KATA & 1070 & AMBANG & 0.000 \\
TOTAL KATA UNIK & 25 & KEKUATAN PEMULIHAN & 0.100 \\
TOTAL EPISODE & 1321 & SIKLUS & 1 \\
TOTAL BARIS & 524 & FUNGSI & Sigmoid \\
& & APITAN & Ya \\
\hline
\end{tabular}

\section{DAFTAR URUTAN FREKUENSI}

\begin{tabular}{|l|r|r|r|r|}
\hline & & & CASE & CASE \\
KATA & FREK & PCNT & FREK & PCNT \\
& & & & \\
\hline FORÊT (forest) & 432 & 40.4 & 1275 & 96.5 \\
MOI (me) & 53 & 5.0 & 363 & 27.5 \\
MIEL (honey) & 44 & 4.1 & 319 & 24.1 \\
TROUVE (find) & 43 & 4.0 & 317 & 24.0 \\
GIBIER (game) & 42 & 3.9 & 308 & 23.3 \\
MANGE (eat) & 38 & 3.6 & 309 & 23.4 \\
SAUVAGES (wild) & 34 & 3.2 & 256 & 19.4 \\
VIE (life) & 33 & 3.1 & 222 & 16.8 \\
CHOSE (thing) & 30 & 2.8 & 228 & 17.3 \\
SE [self] & 27 & 2.5 & 182 & 13.8 \\
VIVRE (to live) & 27 & 2.5 & 214 & 16.2 \\
VILLAGE (village) & 25 & 2.3 & 225 & 17.0 \\
CUEILLE (gathers) & 21 & 2.0 & 158 & 12.0 \\
NOURRITURE (food) & 21 & 2.0 & 173 & 13.1 \\
RAMÈNE(bring back) & 21 & 2.0 & 155 & 11.7 \\
UTILE (useful) & 20 & 1.9 & 136 & 10.3 \\
VIT (lives) & 20 & 1.9 & 155 & 11.7 \\
BAS (low) & 19 & 1.8 & 158 & 12.0 \\
ARBRES (trees) & 18 & 1.7 & 142 & 10.7 \\
DONNE (give) & 18 & 1.7 & 136 & 10.3 \\
MÊME (same) & 18 & 1.7 & 124 & 9.4 \\
CULTIVE(cultivate) & 17 & 1.6 & 129 & 9.8 \\
TUE (kill) & 17 & 1.6 & 127 & 9.6 \\
AIDE (help) & 16 & 1.5 & 88 & 6.7 \\
CHOSES (things) & 16 & 1.5 & 161 & 12.2 \\
& & & & \\
\hline
\end{tabular}

DAFTAR BERDASARKAN ABJAD YANG

\begin{tabular}{|l|r|r|r|r|}
\hline \multicolumn{5}{|c}{ DISORTIR } \\
\hline & & & CASE & CASE \\
KATA & & PCNT & FREK & PCNT \\
\hline AIDE & 16 & 1.5 & 88 & 6.7 \\
ARBRES & 18 & 1.7 & 142 & 10.7 \\
BAS & 19 & 1.8 & 158 & 12.0 \\
CHOSE & 30 & 2.8 & 228 & 17.3 \\
CHOSES & 16 & 1.5 & 161 & 12.2 \\
CUEILLE & 21 & 2.0 & 158 & 12.0 \\
CULTIVE & 17 & 1.6 & 129 & 9.8 \\
DONNE & 18 & 1.7 & 136 & 10.3 \\
FORÊT & 432 & 40.4 & 1275 & 96.5 \\
GIBIER & 42 & 3.9 & 308 & 23.3 \\
MANGE & 38 & 3.6 & 309 & 23.4 \\
MIEL & 44 & 4.1 & 319 & 24.1 \\
MOI & 53 & 5.0 & 363 & 27.5 \\
MÊME & 18 & 1.7 & 124 & 9.4 \\
NOURRITURE & 21 & 2.0 & 173 & 3.1 \\
RAMĖNE & 21 & 2.0 & 155 & 11.7 \\
SAUVAGES & 34 & 3.2 & 256 & 19.4 \\
SE & 27 & 2.5 & 182 & 13.8 \\
TROUVE & 43 & 4.0 & 317 & 24.0 \\
TUE & 17 & 1.6 & 127 & 9.6 \\
UTILE & 20 & 1.9 & 136 & 10.3 \\
VIE & 33 & 3.1 & 222 & 16.8 \\
VILLAGE & 25 & 2.3 & 225 & 17.0 \\
VIT & 20 & 1.9 & 155 & 11.7 \\
VIVRE & 27 & 2.5 & 214 & 16.2 \\
& & & & \\
\hline
\end{tabular}




\section{METODE WARDS}

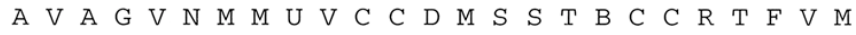
I I R I I O I E $D$ L B B V U E M I T L O N N U O S O E M E R E I

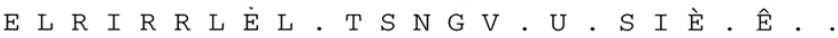
. A E E E . E . I E E E . V E $E$. T . . $G \mathrm{~S}$. I. . . $\mathrm{V}$. . $\mathrm{G}$. $\mathrm{E}$. $\mathrm{S} \mathrm{L} \mathrm{E}$. .

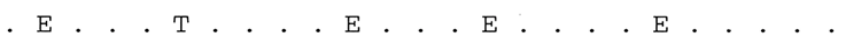

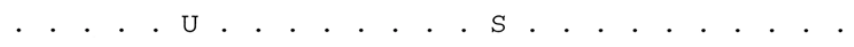

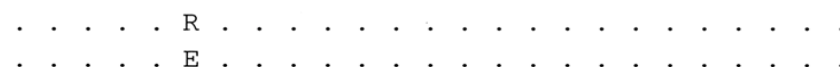

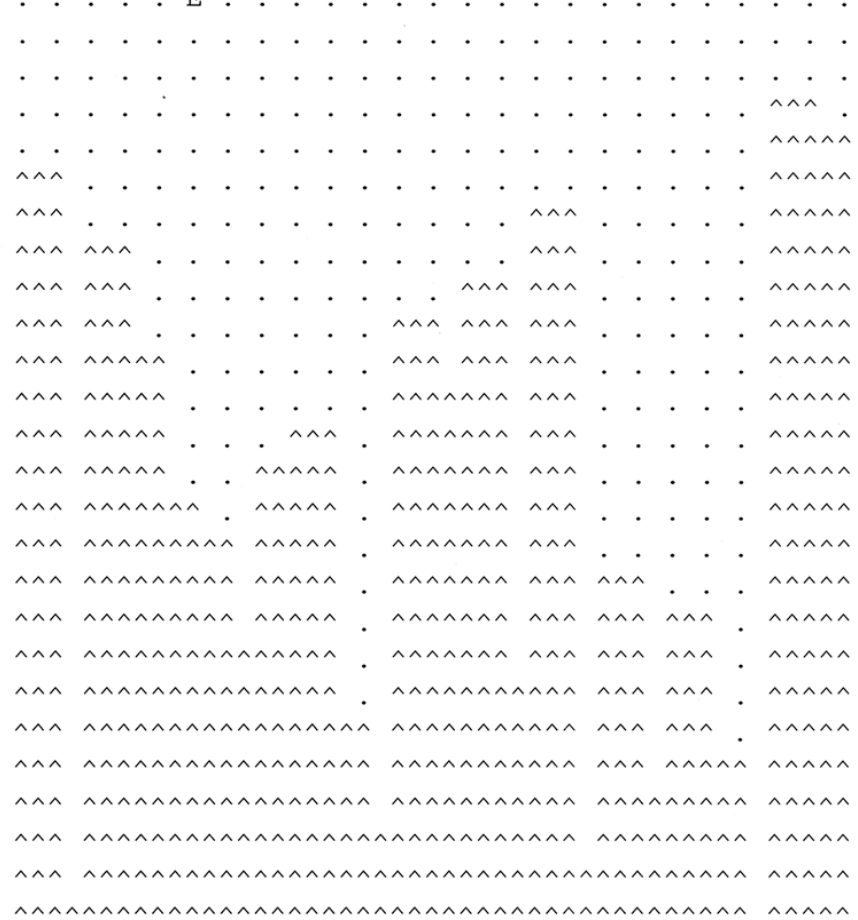

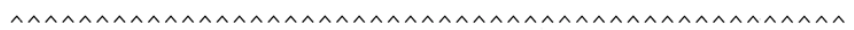




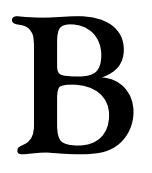

\section{Keamanan Akses}

\section{Antargenerasi Terhadap Sumber Daya (KAASD)}

Topik ini adalah satu-satunya yang paling konsisten diidentifikasi oleh tim CIFOR dalam penilaian kriteria dan indikator selama beberapa tahun yang lalu. Oleh karena itu, kami telah sungguh-sungguh berusaha mencoba memperluas pengembangan $\mathrm{K} \& I$ sehingga mudah diukur dan dapat diandalkan. Walaupun kami telah membuat beberapa kemajuan, kami merasa bahwa masih banyak sekali pertimbangan-pertimbangan pribadi untuk melakukan penilaian-penilaian ini. Kami menyajikan tiga metode tambahan yang kami anggap bermanfaat: Metode Kontinuum Iteratif (MKI); Pembagian Manfaat di antara para Stakeholder; dan Transek Sejarah Lansekap. Untuk memudahkan pemberian skor, kami tampilkan K\&I yang relevan di sini: 


\section{PRINSIP-PRINSIP, KRITERIA DAN INDIKATOR YANG DIUSULKANUNTUK KEAMANANAKSESANTARGENERASI TERHADAPSUMBERDAYA}

\begin{tabular}{|l} 
P. 1 PENGELOLAAN HUTAN MENJAGA ATAU MENINGKATKAN AKSES \\
ANTARGENERASI TERHADAP SUMBER DAYA DAN BERBAGAI \\
MANFAAT EKONOMI SECARA ADIL
\end{tabular}

K. 1.1 Pihak pengelola lokal dapat secara efektif mengendalikan pemeliharaan dan akses terhadap sumber daya

I. 1.1.1 Kepemilikan dan hak pemanfaatan sumber daya (dalam satu generasi atau antargenerasi) jelas dan mengakui klaim yang sudah ada

I. 1.1.2 Berbagai aturan dan norma dalam penggunaan sumber daya dipantau dan ditegakkan pelaksanaannya

I. 1.1.3 Cara-cara untuk mengatasi konflik berfungsi baik tanpa menggunakan kekerasan

I. 1.1.4 Akses terhadap sumber daya dianggap adil oleh masyarakat lokal

I. 1.1.5 Masyarakat lokal merasakan keamanan aksesnya terhadap sumber daya

K. 1.2 Para pengelola hutan memperoleh manfaat ekonomi yang cukup dari hasilhasil hutan yang diambilnya

I. 1.2.1 Mekanisme distribusi manfaat dianggap adil oleh masyarakat lokal

I. 1.2.2 Adanya kesempatan bagi masyarakat lokal dan masyarakat yang menggantungkan hidupnya pada hutan untuk memperoleh pekerjaan dari perusahaan-perusahaan kehutanan

I. 1.2.3 Upah dan tunjangan lainnya sesuai dengan standar nasional dan/atau ILO

I. 1.2.4 Ganti rugi terhadap kerusakan diberikan secara adil 
I. 1.2.5 Berbagai hasil hutan digunakan secara optimal dan adil

K. 1.3 Masyarakat mengaitkan masa depan mereka dan anak-anak mereka dengan pengelolaan sumber daya hutan

I. 1.3.1 Masyarakat menanamkan modal di lingkungannya (misalnya, waktu, tenaga, uang)

I. 1.3.2 Tingkat migrasi keluar rendah ${ }^{6}$

I. 1.3.3 Masyarakat menyadari pentingnya keseimbangan antara jumlah penduduk dengan pemanfaatan sumber daya alam

I. 1.3.4 Anak-anak mendapatkan pendidikan (formal dan informal) tentang pengelolaan sumber daya alam

I. 1.3.5 Perusakan sumber daya alam oleh masyarakat lokal jarang terjadi

I. 1.3.6 Masyarakat memelihara hubungan batin dengan lahan hutan

6 Indikator 1.3.2 dan 3.1.2 bisa menimbulkan kontradiksi. Tingkat migrasi keluar yang rendah (I. 1.3.2) mengindikasikan hubungan antara masa depan penduduk dan anak-anak mereka dengan pemeliharaan hutan; sementara itu pemahaman tentang perlunya keseimbangan antara jumlah penduduk dengan penggunaan sumber daya alam (I. 3.1.2) mungkin membuat mereka memilih untuk bermigrasi keluar. Biasanya kontradiksi ini kemungkinan besar terjadi ketika kondisinya memburuk. 


\section{METODE KONTINUUM ITERATIF (MKI)}

Kami menemukan bahwa metode ini sangat jelas dan bermanfaat bagi mereka yang terlatih dalam bidang antropologi; metode ini kurang dikenal dan lebih sukar bagi para biologiwan. Dalam metode ini diperlukan penilai yang berfungsi sebagai suatu alat yang sensitif dan kompleks, dan yang harus menyadari pengamatannya dan kesimpulan-kesimpulan yang diambilnya tentang sistem-sistem lokal yang sedang dinilai. Semakin banyak pengalaman dan ketrampilan penilai dalam mengamati peserta maka hasil-hasilnya akan lebih dapat dipercaya. Panduan yang bermanfaat untuk melakukan pengamatan peserta dapat diperoleh, misalnya dalam Fetterman (1993); Kleinman dan Copp (1993), Spradley $(1979 ; 1980)$ dan Wolcott (1995).

\section{TUJUAN}

Untuk membantu pengumpulan data kualitatif tentang KAASD secara sistematis (mencakup kepemilikan, hak pakai, dan pembagian manfaat, Prinsip 1).

\section{SAMPEL}

Penilai mencatat pengalamannya sendiri yang berkaitan dengan akses terhadap sumber daya, setiap hari. Usahakan untuk mengambil 'sampel ' tentang konteks dan pengalaman-pengalaman lokal sebanyak mungkin selama kerja lapang berlangsung.

\section{BAHAN}

Lihat formulir MKI di bawah (bawalah beberapa salinan karena Anda akan menghabiskan waktu beberapa hari di lapang + satu). 


\section{METODE}

Metode ini berusaha untuk mendokumentasikan proses peningkatan pengertian yang setiap hari diperoleh dari kerja lapang. Dalam melakukan hal ini, Anda dapat mendokumentasikan peningkatan pengertian Anda tentang rasa aman penduduk dan anak-anak tentang akses mereka terhadap sumber daya. Metode dikembangkan dari ketrampilan-ketrampilan yang digunakan dalam pengamatan peserta.

MKI mengharuskan pencatatan hasil pengamatan tentang keamanan akses antargenerasi terhadap sumber daya, setiap akhir hari kerja di lapang, selama pengamatan berlangsung seminggu sampai sebulan. Gunakan formulir baru setiap hari. Ruang di bawah kontinuum pada formulir MKI adalah untuk merekam bukti-bukti yang mendukung penilaian Anda tentang KAASD. Panduan Cara Pemberian Skor dan Analisis untuk Menilai Kesejahteraan Manusia menyediakan kiat-kiat untuk memperkokoh persepsi Anda terhadap hakhak dan tanggung jawab penduduk.

Setelah hari terakhir pengamatan, kaji ulang semua catatan Anda dan kemudian tentukan hal-hal sebagai berikut:

- Pendapat 'terbaik' Anda, atau kesimpulan-kesimpulan Anda berdasarkan semua hari pengamatan, untuk tempat, arah dan kecepatan perubahan, pada kontinuum ini. Untuk kecepatan perubahan, gunakan warna merah untuk cepat, kuning untuk sedang, dan hijau untuk lambat/stabil.

- Pertimbangkan variasi dalam catatan-catatan Anda selama hari-hari pengamatan. 


\section{WAKTU YANG DIPERLUKAN}

Penilai sebaiknya menghabiskan waktu paling sedikit satu minggu di lapang. Pencatatan data setiap hari kira-kira 20 menit hingga setengah jam, tergantung tingkat produktivitas pengamatan pada hari itu.

\section{ANALISIS DAN PEMBERIAN SKOR}

Sekarang Anda memiliki kumpulan bahan-bahan - kasus-kasus, bukti-bukti, contoh-contoh - yang dapat Anda masukkan ke dalam lembar isian induk K\&I. Sama seperti metode-metode lain, Anda akan menentukan skor bahanbahan baru ini ( 1 = tidak lestari; 10 = paling lestari), dan ketik versi ringkas di bawah kriteria atau indikator yang sesuai, catat juga sumbernya.

Lihat diskusi yang berkaitan dengan MKI dalam Bagian C, pada bagian 'Hak dan kemampuan untuk mengelola hutan secara bersama dan adil'. 


\title{
FORMULIR SAMPEL MKI
}

\section{Formulir Metode Kontinuum Iteratif (MKI)}

\section{'Keamanan Akses Antargenerasi Terhadap Sumber Daya'}

\begin{abstract}
tidak aman 4 aman

3 Juli 1996 [sampel dari catatan lapang Emily Harwell]

Cukup banyak bukti (dalam berbagai bentuk - pertumbuhan ulang ladang, lokasi rumah panjang tua, pemberian barang antik sebagai tanda perjanjian, sejarah lisan) dapat dikumpulkan menjadi pendukung bahwa masyarakat Kelayang sudah hidup lama dan memiliki hak-hak terhadap sumber daya dalam wilayahnya. Interaksi dengan HPH dilakukan melalui hubungan pemilik HPH dengan kekuasaan lokal dan masyarakat lokal dan menyebabkan tekanan yang menjadi sumber munculnya kebutuhan lokal.

Namun, kegiatan-kegiatan penebangan pohon yang mengambil lebih banyak pohon dan meluas hingga pinggiran sungai (tempat ladang berada) bertentangan dengan aturan resmi dan keluhan-keluhan lokal yang menunjukkan bahwa HPH tidak terlalu mempedulikan hak-hak lokal dan akses masyarakat lokal seperti yang dikeluhkan oleh pemilik. Apatisme aparat pemerintah (kecamatan, polisi, kehutanan) terhadap keluhan-keluhan ini juga menjadi tanda buruk tentang kelanjutan akses mayarakat lokal terhadap hutan.
\end{abstract}

\section{Juli 1996 [sampel dari catatan lapang Carol J. Pierce Colfer]}

Hak-hak terhadap akses di desa ini tampak tetap berfungsi. Melihat anggota rumah keluarga saya tetap membagi tumbuhan paku-pakuannya, konsisten dengan adat [kebiasaan] umum.

Kepala keluarga menunjukkan kemampuannya mengerti ketika berurusan dengan saya (sebagai pihak luar).

Kepala keluarga mencari tiga pria lokal untuk saya (salah seorang adalah KN [seorang kepala nelayan]) yang dapat membantu saya, membagi keuntungan secara lokal.

Anggota masyarakat pergi untuk membuka ladang-ladang mereka (seperti yang lain di tempat yang sama).

Para wanita menganyam barang-barang untuk dijual melalui proyek - konservasi.

Pertimbangkan paling sedikit keamanan kepemilikan lahan/pohon, hak-hak guna, pekerjaan, dan mekanisme-mekanisme pembagian manfaat hutan lainnya yang mungkin untuk diri mereka sendiri dan anak-anak mereka di masa depan. 


\section{PEMBAGIAN MANFAAT DI ANTARA PARA STAKEHOLDER: METODE DISTRIBUSI KERIKIL}

Kami menganggap pembagian manfaat sebagai bagian dari 'akses antargenerasi terhadap sumber daya', walaupun beberapa peneliti lebih suka menempatkannya secara terpisah (misalnya, Perez 1996). Cara apa pun yang dipakai, pembagian manfaat ini oleh semua tim CIFOR dianggap sebagai isu penting dalam pengelolaan hutan lestari.

\section{TUJUAN}

Untuk menilai persepsi para stakeholder yang berbeda tentang distribusi manfaat hutan di antara mereka (Kriteria 1.2).

\section{PESERTA}

Pilih 12-15 peserta dari masing-masing kelompok stakeholder yang terpenting dalam kawasan. Pastikan untuk menggunakan metode ini dengan jumlah pria dan wanita yang kira-kira seimbang; dan juga perhatikan perbedaanperbedaan sosial lain yang penting secara lokal (umur, etnis, dll.). Apakah penyortiran kerikil akan dilakukan secara individu atau dalam kelompokkelompok yang sama sesuai dengan kondisi lokal dan pengalaman Anda selama ini dengan metode-metode lain dalam bidang ini. Cara apa pun yang dipakai, apakah Anda bekerja dengan kelompok-kelompok atau individu, pastikan untuk mencatat data demografi (umur, jender, etnis, pekerjaan, dll.). 


\section{BAHAN}

Formulir-formulir yang mirip dengan formulir sederhana 'pembagian manfaat' di bawah, direvisi untuk kondisi lokal (misalnya, dengan para stakeholder yang relevan secara lokal dan sumber daya hutan, bahasa-bahasa daerah). Kami menyarankan membatasi jumlah stakeholder sekecil mungkin tanpa mempengaruhi analisis (3-10). Sebuah matriks yang besar, digunakan untuk kelompok, mungkin bermanfaat, atau piring-piring yang mewakili stakeholder atau sumber daya yang di dalamnya para peserta dapat mendistribusikan kerikil.

\section{METODE}

Bila memungkinkan, gunakan bahasa daerah dalam wawancara Anda. Tujuannya adalah agar manfaat utama dari hutan didaftar di bagian atas formulir, sebagai kolom ( $\mathrm{a}-\mathrm{f}$, dalam contoh Kalimantan di bawah). Pastikan untuk mengetahui penggunaan hutan untuk kebutuhan subsisten penting yang mungkin ada dalam kawasan Anda. Kolom pertama berisi daftar stakeholder/kelompok pengelola yang memperoleh manfaat hutan.

Gunakan formulir yang direvisi, tanyakan kepada setiap peserta atau kelompok peserta untuk memberikan 100 kerikil di antara para stakeholder, dalam masing-masing kolom, a-f, berdasarkan kelompok-kelompok yang mendapat pembagian manfaat paling besar. Ingat bahwa masing-masing kolom ketika dijumlahkan harus bernilai 100. Tanyakan kepada para peserta untuk memikirkan hutan dalam kawasan mereka dan catat persepsi mereka tentang pembagian manfaat hutan yang telah didaftar. Anda tidak perlu terlalu memperhatikan ketepatan pembagian manfaat yang sebenarnya, tetapi yang lebih penting adalah persepsi para peserta tentang pembagian tersebut. 
Bila para peserta pandai, nilai persentase bisa dibuat. Jika tidak Anda dapat mengurangi jumlah kerikil dan kemudian nanti diubah dalam persen. Para peserta dapat memberikan 100 kerikil mereka tanpa menghitung (kemudian dihitung oleh para peneliti). Ini mungkin tidak terlalu membosankan bagi semua yang terlibat.

\section{WAKTU YANG DIPERLUKAN}

Brocklesby dkk. (1997) melaporkan menghabiskan waktu 3 jam per orang untuk melatih dan menyesuaikan formulir, 26 jam untuk melakukan 40 wawancara dengan 95 peserta, dan 12 jam untuk memasukkan data dan analisis.

Sardjono dkk. (1997) melaporkan menghabiskan waktu kira-kira 15 menit per orang dalam wawancara ini ( $>10$ jam di masing-masing lokasi untuk dua lokasi, untuk mewawancarai $44-50$ peserta).

\section{ANALISIS DAN PEMBERIAN SKOR ${ }^{7}$}

Lakukan analisis data. Data ini dapat langsung dimasukkan ke dalam lembar isian pembagian manfaat pada sistem komputer. Anda perlu memperhatikan distribusi akses terhadap produk-produk khusus, dan secara keseluruhan, akses yang dirata-ratakan. Untuk sebuah kelompok dengan anggota 12-15 wawancara/peserta, hitung skor rata-rata untuk masing-masing hasil hutan oleh stakeholder atau kelompok pengguna yang didaftarkan dalam formulir. Ini memberikan ide yang bagus mengenai persepsi kelompok dengan tentang

7 Panduan tambahan untuk analisis dapat dilihat dalam Panduan Cara Pemberian Skor dan Analisis untuk Menilai Kesejahteraan Manusia. 
distribusi manfaat - walaupun distribusi manfaat moneter mungkin bobotnya lebih besar. Anda akan mengulangi prosedur ini untuk para peserta dari kelompok-kelompok yang berbeda, dan membandingkan hasilnya. Dengan menghitung skor rata-rata, masing-masing di sepanjang baris (kolom terakhir pada formulir), Anda dapat memperoleh baris kasar akses umum, yang mungkin juga informatif.

Karena jumlah stakeholder yang berbeda pada formulir akan menghasilkan skor rata-rata yang berbeda dan tempat pelaksanaan yang berbeda mempunyai rasa tingkat keadilan yang berbeda, kami tidak dapat menyediakan 'garis pemisah' yang akan menunjukkan persepsi lokal tentang 'distribusi manfaat yang adil'. Namun, bila skor rata-rata sangat berbeda di antara kategori-kategori stakeholder, ini menunjukkan 'tanda bahaya' untuk Kriteria 1.2. Ketidakseimbangan yang jelas dalam hal manfaat moneter juga merupakan sebab keprihatinan.

Dalam contoh Kamerun di bawah, penduduk asli Mbongo dipandang oleh para responden menerima lebih dari dua kali semua manfaat daripada yang diperoleh stakeholder lainnya. Tingkat akses terhadap manfaat ini menunjukkan tingkat ketergantungan yang tinggi pada sumber daya hutan. Kalau dilihat dari kolom 'uang' akan terlihat satu pola yang berbeda. Aparat pemerintah, perusahaan kayu dan Cameroon Development Corporation (CDC) dipandang sebagai pihak-pihak yang paling banyak mendapat manfaat. 


\section{FORMULIR SAMPEL DAN ANALISIS SAMPEL}

\section{Pembagian Manfaat - Metode Distribusi Kerikil}

Untuk masing-masing kolom (a-f) bagilah 100 kerikil di antara para stakeholder atau kelompok-kelompok pengguna di bawah. Kalau dijumlahkan masing-masing kolom harus bernilai 100. Kolom terakhir adalah jumlah nilai dalam baris tersebut dibagi enam untuk mendapatkan nilai rata-rata.

\begin{tabular}{|c|c|c|c|c|c|c|c|}
\hline & \multicolumn{7}{|c|}{ M anfaat $\mathrm{Hutan}$} \\
\hline & Uang & Kayu & Satwa & Makanan & $\begin{array}{l}\text { Meds. } \\
\text { O bat }\end{array}$ & \begin{tabular}{|c|} 
Serat \& \\
HHNK lain
\end{tabular} & TO TAL $/ 6$ \\
\hline $\begin{array}{c}\text { Stakeholder/Kelom pok } \\
\text { pengguna }\end{array}$ & (a) & (b) & (c) & (d) & (e) & $(\uparrow)$ & \\
\hline \multicolumn{8}{|l|}{ Dayaks (indijenus) } \\
\hline \multicolumn{8}{|l|}{ Kutai (indijenus) } \\
\hline \multicolumn{8}{|l|}{ Transmigran } \\
\hline \multicolumn{8}{|l|}{ Para pekerja HPH } \\
\hline \multicolumn{8}{|l|}{ Pelacuran kamp kerja } \\
\hline \multicolumn{8}{|l|}{ Kontraktor swasta } \\
\hline \multicolumn{8}{|l|}{ Karyawan perusahaan } \\
\hline \multicolumn{8}{|l|}{ Pegawai pemerintah } \\
\hline \multicolumn{8}{|l|}{ Pedagang } \\
\hline \multicolumn{8}{|l|}{ Konsumen } \\
\hline Total & 100 & 100 & 100 & 100 & 100 & 100 & \\
\hline
\end{tabular}




\section{Skor rata-rata semua Manfaat oleh Stakeholder di Mbongo}

(Brocklesby dkk. 1997)

\begin{tabular}{|l|c|c|c|c|c|c|c|}
\hline \multicolumn{1}{|c|}{ Stakeholder } & $\begin{array}{c}\text { Daging } \\
\text { satwa }\end{array}$ & Makanan & $\begin{array}{c}\text { Obat- } \\
\text { obatan }\end{array}$ & Uang & $\begin{array}{c}\text { HHNK } \\
\text { (dijual) }\end{array}$ & Tiang & Total \\
\hline Pemburu & 42,93 & 7,98 & 2,60 & 6,02 & 10,75 & 1,57 & 11,97 \\
\hline Dokter Tradisional & 2,22 & 3,29 & 45,12 & 6,00 & 3,89 & 4,36 & 10,81 \\
\hline Pegawai pemerintah & 12,82 & 5,49 & 5,42 & 17,73 & 2,31 & 16,73 & 10,08 \\
\hline HPH & 2,81 & 2,79 & 1,14 & 15,42 & 0,64 & 30,13 & 8,82 \\
\hline Penebang & 2,74 & 3,33 & 1,54 & 8,24 & 4,25 & 14,04 & 5,69 \\
\hline Penduduk Mbongo & 15,69 & 47,68 & 16,34 & 12,83 & 61,31 & 10,83 & 27,45 \\
\hline Nigeria & 8,60 & 20,58 & 7,85 & 7,82 & 13,67 & 4,40 & 10,49 \\
\hline Cam. Dev. Corp. & 2,20 & 5,31 & 1,73 & 17,56 & 0,81 & 9,85 & 6,24 \\
\hline Mt. Cam. Proj. & 9,99 & 3,60 & 18,27 & 8,38 & 2,37 & 8,09 & 8,45 \\
\hline
\end{tabular}


Diagram batang berikut (dari pengujian metode Diaw dkk. 1998) menunjukkan distribusi manfaat hutan dalam suatu kawasan hutan yang kaya dan yang miskin. Kepentingan pemerintah dan perusahaan kayu dalam hal akses mereka terhadap uang tunai dan kayu mencerminkan suatu pola yang lebih umum di seluruh lokasi riset kami.

\section{Pembagian Manfaat di antara Para Stakeholder, Mbeka'a (Kawasan Terfragmentasi), Kamerun}

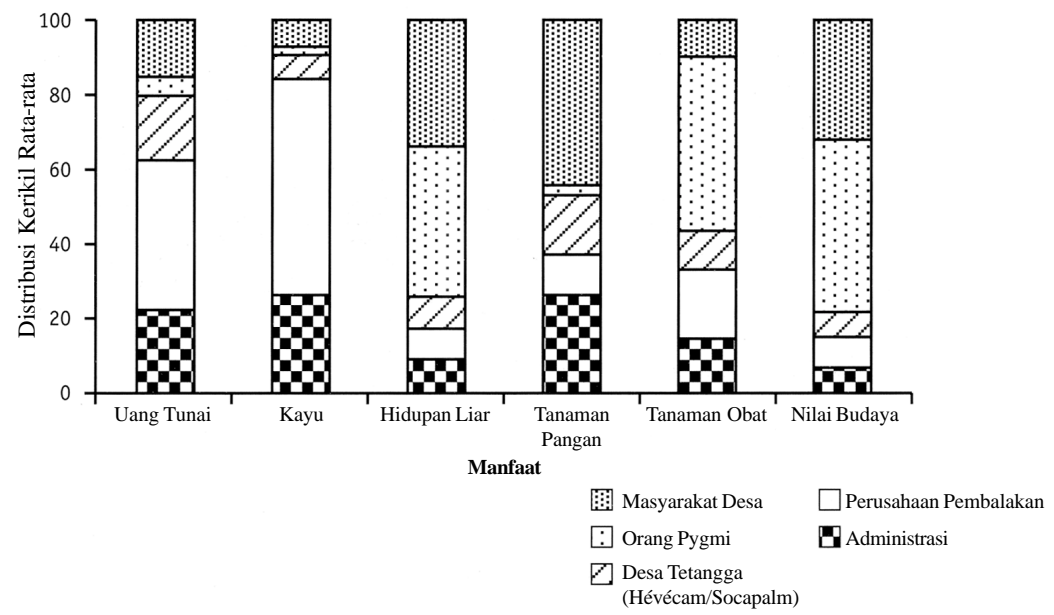


Pembagian Manfaat di antara Para Stakeholder, Mengomo (Kawasan Hutan yang Kaya), Kamerun

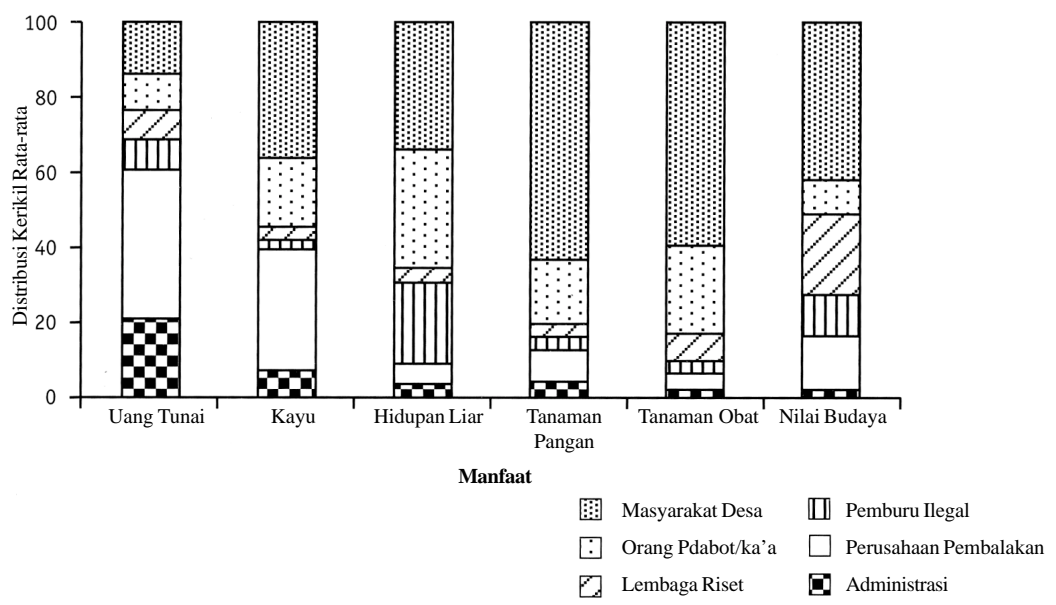




\section{TRANSEK SEJARAH LANSEKAP ${ }^{8}$}

\section{TUJUAN}

- Untuk menentukan arah perubahan pengelolaan dan penggunaan sumber daya di masa lalu dan masa depan di dalam kawasan (Kriteria 1.1 dan 1.3); dan

- Untuk memahami perasaan penduduk tentang keamanan, keadilan dan perhatian terhadap masa depan (Kriteria 1.1, 1.2, dan 1.3)

\section{PESERTA}

Anda akan memerlukan seorang fasilitator dan seorang pencatat. Berdasarkan pengalaman Anda sebelumnya dengan dua jenis kelompok (homogen dan heterogen), pilih kelompok yang mampu berkomunikasi paling baik antara diri Anda dan anggota-anggota kelompok. Kelompok kecil 5-10 orang adalah yang terbaik; perwakilan jender yang seimbang adalah terbaik - mungkin dalam kelompok-kelompok yang terpisah.

\section{BAHAN}

Anda memerlukan lembar-lembar kertas yang besar untuk menggambar transek-transek, dan beberapa pena berwarna untuk menggambar perbedaan entitas yang terdapat pada transek-transek.

8 Lihat Poffenberger dan McGean (19931,b), untuk contoh-contoh transek lansekap masa lalu dan sekarang di dua tempat (Filipina dan Thailand); atau the Participatory Rural Appraisal Handbook (1990) untuk contoh-contoh Afrika. Metode lain, Akses Generasi terhadap Sumber Daya: Metode Distribusi Kerikil, sangat disukai dalam pengujian kami. Semuanya dijelaskan dalam PPD (KAASD) dan dapat mengganti transek sejarah lansekap. 


\section{METODE}

Anda perlu mengkaji ulang K\&I yang informasinya lebih lanjut akan Anda perlukan dan pertimbangkan isu-isu yang ingin Anda bahas sebelum Anda bertemu dengan kelompok. Lanjutkan mencatat semua informasi K\&I ketika informasi ini muncul. Paling sedikit Anda perlu memperhatikan jumlah dan jenis-jenis penutup hutan, lahan-lahan pertanian, populasi penduduk, jalan-jalan dan sungai-sungai.

Tanyakan kelompok Anda untuk memilih suatu tempat yang sesuai di dekat desa, atau tempat-tempat mereka bekerja, yang mereka kenal dengan baik. Pergilah ke tempat tersebut bersama-sama dengan kelompok. Mulailah menggambar transek dari keadaan sekarang. Ini paling mudah dan menolong anggota kelompok untuk melihat keadaaan secara nyata. Kemudian tanyakan penduduk yang lebih tua untuk menggambar sebuah transek di tempat yang sama ketika mereka muda (20 tahun yang lalu, 50 tahun yang lalu). Kemudian kembali pada semua kelompok dan dapatkan visi mereka - dalam bentuk sebuah transek imaginatif - tentang keadaan pada 20 tahun yang akan datang. Anda akan memerlukan transek paling sedikit untuk tiga periode, termasuk yang lalu, saat ini dan yang akan datang.

Porro dan Porro (1998) mencatat ketidaktepatan dalam membuat beberapa transek di beberapa kawasan yang tergenang. Diaw dkk. (1998) dan Tchikangwa dkk. (1998) menjelaskan ketelitian tambahan yang dapat Anda peroleh saat mengunjungi lokasi transek; dan sebaliknya lebih banyak kemudahan yang didapatkan dengan lebih banyak peserta yang terlibat jika para peserta membayangkan lokasi transek. Di beberapa tempat, di mana penduduk membuat ladang di sepanjang sungai atau jalan, mungkin perlu untuk membuat transek ke arah belakang (pada sudut $90^{\circ}$ ) dari jalur 
transportasi, untuk menggambarkan keanekaragaman lansekap dengan lebih memadai. McDougall (1998) mencatat kemiripan tata guna lahan di sepanjang sungai, misalnya di Kalimantan Timur.

\section{WAKTU YANG DIPERLUKAN}

Fasilitator dan pencatat akan membutuhkan waktu satu atau dua jam untuk mempersiapkan diri. Semakin jauh penilaian Anda, akan semakin perlu untuk melihat kembali lembar isian induk K\&I dan memeriksa jenis informasi mana yang masih belum ada. Waktu yang dibutuhkan oleh tiap kelompok adalah sekitar satu jam.

\section{ANALISIS DAN PEMBERIAN SKOR}

Berlaku prosedur yang sama. Pertama siapkan sebuah lembar isian transek yang relevan dengan $\mathrm{K} \& \mathrm{I}$ yang didaftar. Catat informasi yang Anda terima berkaitan dengan $\mathrm{K} \& \mathrm{I}$ yang spesifik, berikan skor terhadap masing-masing kasus atau bagian dari bukti mulai dari satu (paling tidak mendukung kelestarian) hingga sepuluh (paling mendukung kelestarian). Jika, misalnya, penduduk lokal mendirikan sebuah sekolah baru, ini dapat menjadi bukti untuk Indikator 1.3.1, atau jika ada tempat yang hutannya dibakar oleh penduduk lokal, informasi ini akan berkaitan dengan Indikator 1.3.5.

Setelah Anda menilai semua informasi, Anda dapat memasukkan skor dan analisis, dalam formulir skor yang diringkas, ke dalam daftar induk K\&I. 


\section{SAMPEL TRANSEK}

Transek masa lalu, sekarang, masa depan di Nkout, Kamerun (dari Tiani dkk. 1997)

Transect Du Terroir Réalié Ã Nkout

Le 04 Juin 1997 Par 25 Femmes et 4 Hommes

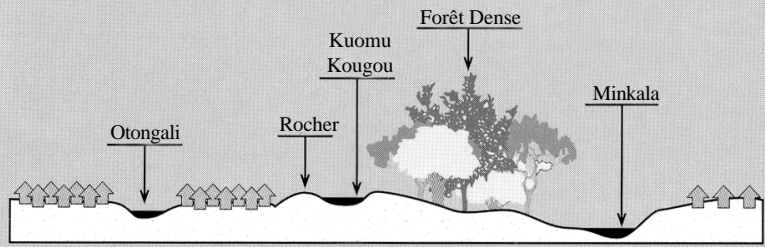

1960
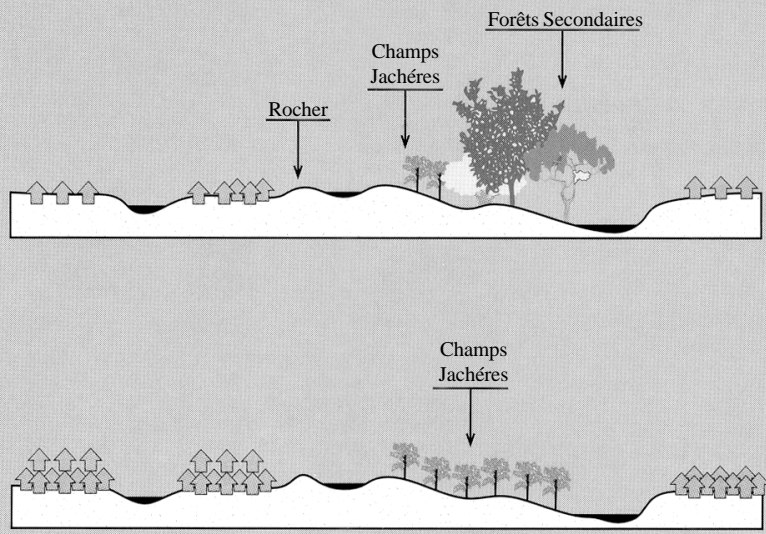


\section{Hak dan Kemampuan untuk Mengelola Hutan secara Bersama dan Adil}

'Hak dan kemampuan untuk mengelola hutan secara bersama dan adil' menggantikan kalimat 'Partisipasi dalam Pengelolaan Hutan,' yang digunakan dalam versi sebelumnya dalam pengembangan K\&I. Seperti yang telah disebutkan dalam PPD, kami menemukan asumsi yang tidak beralasan bahwa penduduk lokal harus berpartisipasi dalam sistem pengelolaan perusahaan-perusahaan HPH atau lembaga-lembaga pemerintah (Colfer dan Wadley 1996). Kenyataannya, penduduk lokal umumnya telah melakukan banyak pengelolaan oleh mereka sendiri. Oleh karena itu diperlukan perumusan ulang dan pengungkapan kembali prinsip kami.

Dalam bagian ini, kami menawarkan tiga metode pelengkap: Penyortiran Kartu Skor; Metode Kontinuum Iteratif (MKI); dan Panduan bagi Peneliti untuk Menilai Partisipasi. Untuk memudahkan pemberian skor, kami tampilkan kembali K\&I yang relevan di sini: 


\title{
PRINSIP-PRINSIP, KRITERIA DAN INDIKATOR YANG DIUSULKANUNTUK MENGELOLA HUTANSECARA BERSAMA DANADIL
}

\author{
P.2 STAKEHOLDER YANG RELEVAN MEMILIKI HAK DAN KEMAMPUAN YANG \\ DIAKUI UNTUK MENGELOLA HUTAN SECARA BERSAMA DAN ADIL
}

K. 2.1 Adanya berbagai mekanisme yang efektif untuk melakukan komunikasi dua arah antara para stakeholder dalam kaitannya dengan pengelolaan hutan

I. 2.1.1 > 50\% dari pegawai Departemen Kehutanan dan Perkebunan dan karyawan HPH dapat berbicara dalam satu atau beberapa bahasa lokal, atau > 50\% wanita lokal dapat menggunakan bahasa yang digunakan oleh HPH dalam berinteraksi

I. 2.1.2 Para stakeholder lokal bertemu dengan dengan frekuensi yang cukup, keragaman lokal cukup terwakili, dan dengan kualitas interaksi yang cukup

I. 2.1.3 Kontribusi masing-masing stakeholder saling dihormati dan dihargai secara wajar

K. 2.2 Para stakeholder lokal memiliki pengetahuan yang lengkap tentang penggunaan sumber daya hutan (termasuk pengetahuan tentang kelompok-kelompok pengguna hutan dan peranan jender), dan juga pengetahuan tentang rencana pengelolaan hutan sebelum rencana tersebut dilaksanakan

I. 2.2.1 Adanya rencana/peta-peta yang menunjukkan pengintegrasian berbagai penggunaan hutan oleh berbagai stakeholder yang berbeda

I. 2.2.2 Rencana yang diperbarui, studi-studi dasar dan peta dapat diperoleh dengan mudah, yang menunjukkan rincian kawasan seperti penebangan hutan dan pembangunan jalan, disertai kerangka waktunya

I. 2.2.3 Studi-studi dasar tentang sistem masyarakat lokal juga tersedia dan diacu

I. 2.2.4 Pegawai pengelola hutan mengakui adanya berbagai kepentingan dan hak stakeholder lainnya

I. 2.2.5 Pengelolaan HHNK mencerminkan kepentingan dan hak-hak stakeholder lokal

K. 2.3 Ada kesepakatan tentang hak-hak dan berbagai kewajiban stakeholder yang relevan

I. 2.3.1 Tingkat konflik yang ada dapat diterima oleh para stakeholder 


\section{PENYORTIRAN KARTU SKOR}

\section{TUJUAN}

- Menilai masing-masing stakeholder lokal yang terlibat dalam pengelolaan hutan (Kriteria 2.1, 2.3, dan Indikator 2.2.4); dan

- Menilai tingkat interaksi antar stakeholder secara lokal (Kriteria 2.1)

\section{PESERTA}

Anda akan membutuhkan empat hingga enam kelompok stakeholder untuk menerapkan metode ini (mencakup para pekerja $\mathrm{HPH}^{9}$, pegawai Departemen Kehutanan dan Perkebunan dan lainnya, dan berbagai kelompok pemakai dan kelompok masyarakat). Bila mungkin, dapatkan jumlah peserta pria dan wanita yang seimbang. Anda dapat melakukan wawancara tunggal atau dalam kelompok yang terdiri dari 5-15 orang. Paling sedikit Anda akan membutuhkan 12-15 peserta dari tiap kelompok stakeholder, dan dari mereka inilah Anda bisa menarik kesimpulan. Pastikan untuk mengikutsertakan para pengelola HPH yang akan Anda butuhkan untuk memahami persepsipersepsi mereka mengenai Indikator 2.2.4.

Jangan lupa sektor swasta skala kecil dan sektor-sektor informal (restoran-restoran, para pemasok, pelacuran, pelayanan transportasi, dll.). 


\section{BAHAN}

Anda akan membutuhkan beberapa kartu berwarna ${ }^{10}$, pensil dan penghapus. Tulis enam jenis stakeholder yang aktif di kawasan tersebut, masing-masing pada sebuah kartu berwarna yang berbeda. Anda juga akan memerlukan formulir (lihat contoh di bawah).

\section{METODE}

Siapkan formulir Penyortiran Kartu Skor, sama dengan contoh yang disajikan di bawah. Daftar stakeholder yang telah Anda pilih merupakan kolom pertama pada bagian kiri lembar isian. Berdasarkan pemahaman Anda tentang kondisi-kondisi lokal yang baru saja Anda peroleh, lakukan modifikasi untuk keempat pertanyaan dalam formulir contoh, sehingga pertanyaan-pertanyaan tersebut mewakili isu-isu penting dalam pengelolaan di kawasan Anda. Pertanyaan-pertanyaan ini mewakili (bila dikombinasi) 'pengelolaan hutan'. Kegunaan hasil-hasil Anda akan bergantung pada ketepatan pertanyaan perwakilannya . Mintalah bantuan penduduk lokal yang memiliki informasi ini.

Sardjono dkk. (1997) menyiapkan pertanyaan-pertanyaan tersebut menurut empat topik: pengetahuan tentang tanaman-tanaman obat, sanksi-sanksi terhadap pengumpulan buah-buah di hutan secara ilegal, memilih bagian kawasan hutan yang ditebang untuk sawah, dan memecahkan masalah-masalah dengan perusahaan-perusahaan HPH. Di Kamerun, Tiani dkk. (1997) mengganti pertanyaan-pertanyaan dengan pengetahuan tentang satwa liar,

${ }^{10}$ Beberapa peneliti di Kamerun tidak lagi menggunakan kartu-kartu berwarna dan hanya meminta penduduk mengisi formulir secara sederhana. Diaw dkk. (1998) mengubah formulir ini menjadi metode 'penyortiran kerikil'. 
ijin menebang suatu jenis pohon, dan sanksi-sanksi untuk penangkapan ikan menggunakan racun. Dalam memilih pertanyaan-pertanyaan Anda, cobalah mendapatkan gambaran aspek-aspek yang berbeda dalam pengelolaan hutan dalam kawasan hutan (berkaitan dengan hasil-hasil hutan, para pengguna lokal dari kedua pihak, dan fungsi-fungsi ${ }^{11}$ pengelolaan yang berbeda).

Sebelum memulai pertemuan dengan kelompok Anda, kaji ulang daftar K\&I dalam kotak di atas, sehingga informasi yang Anda perlukan jelas bagi diri Anda sendiri. Ide-ide dan persepsi-persepsi yang diungkapkan sambil mendiskusikan formulir dengan penduduk mungkin bermanfaat bagi Anda sebagai hasil-hasil yang terukur. Anda perlu mencatat komposisi demografi kelompok Anda (etnis, jender, umur, pekerjaan, tingkat pendidikan, dll.) untuk digunakan dalam analisis data selanjutnya.

Tunjukkan kartu kepada responden atau kelompok, dan jelaskan bahwa masing-masing kartu mewakili sebuah kelompok penduduk yang berkepentingan dengan hutan-hutan lokal. Tanyakan pertanyaan pertama Anda, dan minta mereka untuk memilih dengan mengurutkan stakeholder (diwakili oleh kartu), dari 1 hingga 6 (jika ada 6 stakeholder), berdasarkan kepentingan peran masing-masing stakeholder dalam aspek-aspek tertentu pengelolaan hutan ${ }^{12}$.

${ }^{11}$ Beberapa fungsi pengelolaan penting berkaitan dengan pengetahuan penduduk (setara dengan 'rencana pengelolaan' tradisional), berbagai aturan, pemecahan konflik dan berbagai sanksi.

12 Dalam pengujian sebelumnya, para peserta diminta untuk membuat formulir yang berbeda dan memberikan peringkat kepentingan dan berdasarkan frekuensi interaksi. Kami mendapat pandangan yang bervariasi tentang dasar peringkat yang kedua, sebagian karena konsep ini sulit dijelaskan. 
Satu masalah yang kami temui bersumber pada keperluan masing-masing peserta untuk bersikap analitis sehingga mampu mengurutkan peringkat masing-masing dari enam stakeholder - untuk keperluan analisis selanjutnya. Para peneliti menemukan bahwa beberapa penduduk menganggap dua stakeholder memiliki peringkat yang sama; kasus-kasus lain menemukan bahwa responden tidak mengetahui apa-apa tentang satu atau lebih stakeholder. Skor-skor bagi dua stakeholder yang peringkatnya sama (misalnya, dua stakeholder berada pada peringkat 3) dapat dirata-ratakan (3+4=7 dibagi 2), menghasilkan skor 3,5 untuk masing-masing stakeholder. Atau misalnya, jika tiga stakeholder tidak dikenal oleh responden, para stakeholder tersebut dapat diasumsikan tidak penting dalam persepsi responden. Masing-masing dapat diberi peringkat ratarata pada tiga peringkat terakhir (jika ada enam stakeholder, skor-skor dari stakeholder yang tidak dikenal menjadi 5 - nilai tengah dari 4, 5 dan 6).

Catat peringkat-peringkat tersebut dalam formulir. Lanjutkan pertanyaan Anda berikutnya, hingga Anda memiliki peringkat stakeholder untuk keempat pertanyaan. Bila ada ketidaksepakatan yang penting dalam suatu kelompok, isilah pada formulir yang terpisah untuk mereka yang persepsinya berbeda. Catat jumlah peserta yang diwakili oleh masing-masing formulir.

\section{ANALISIS DAN PEMBERIAN SKOR ${ }^{13}$}

Anda ingin menentukan apakah ada atau tidak persepsi yang sama tentang kepentingan relatif stakeholder yang berbeda. Ini berarti Anda membandingkan hasil-hasil formulir dari pertemuan stakeholder yang berbeda

${ }^{13}$ Pandangan tambahan untuk analisis data ini tersedia dalam Panduan Cara Pemberian Skor dan Analisis untuk Menilai Kesejahteraan Manusia. 
yang telah Anda lakukan. Anda akan memasukkan hasil-hasil pertemuan Anda ke dalam sebuah lembar isian penyortiran kartu. Proses ini membutuhkan empat tahap:

Tahap pertama: Kategorikan kelompok-kelompok/individu-individu ke dalam kelompok stakeholder/kelompok pengguna atau kategori sosial. Misalnya, mungkin Anda mempunyai hasil-hasil dari tiga pertemuan dengan para wanita (dari dua kelompok etnis dan satu kelompok pekerja). Untuk memastikan persepsi-persepsi wanita yang lebih umum, mungkin Anda dapat mengkombinasikan jawaban-jawaban semua wanita, dan membandingkannya dengan jawaban-jawaban pria secara umum. Atau mungkin Anda telah melakukan serangkaian pertemuan dengan penduduk dari kelompok etnis tertentu, dengan beberapa wawancara tunggal. Hasilhasil ini dapat dikombinasikan untuk mewakili persepsi umum suatu kelompok etnis. Anda tentu perlu menguji hasil-hasil wawancara pegawai pengelolaan $\mathrm{HPH}$.

Tahap kedua: Untuk memulai memasukkan data, ambil formulir yang sudah diisi (hasil-hasil dari satu pertemuan atau satu peserta pertama). Rataratakan jawaban-jawaban dari keempat pertanyaan dari formulir tersebut untuk mendapatkan nilai tengah peringkat stakeholder, yang mewakili persepsi peserta tentang kepentingan masing-masing stakeholder dalam pengelolaan hutan yang lebih umum. Proses yang sama ini akan diulang untuk masing-masing formulir, karena Anda akhirnya akan merataratakannya melalui jawaban-jawaban kelompok lokal yang relevan.

Tahap ketiga: Pindahkan skor rata-rata dari tiap-tiap formulir ke dalam sebuah file komputer yang terpisah untuk masing-masing kategori penting (kelompok pengguna, kategori sosial atau stakeholder). Anda kemudian akan memperoleh 
'nilai tengah secara keseluruhan' dari semua pertemuan atau individu-individu yang mewakili stakeholder/kelompok pengguna tertentu atau kategori sosial tertentu.

Tahap keempat: Dengan melihat masing-masing stakeholder/peserta yang berbeda, Anda dapat melihat ada atau tidak persepsi yang sama tentang hak-hak dan tanggung jawab di antara stakeholder/peserta (Kriteria 2.3). Jika semua kelompok peserta memberi urutan kepentingan yang kira-kira sama, maka ada kesepakatan. Jika urutan ini sangat berbeda, maka jelas ada ketidaksepakatan yang cukup besar.

Anda dapat membuat estimasi skor dalam lembar isian induk Anda untuk Kriteria 2.3 dengan memberikan skor 1 untuk ketidaksepakatan tentang penetapan urutan dan skor 10 untuk kesepakatan penuh. Kebanyakan skor akan berada di antara dua skor yang ekstrim ini, walaupun dalam kasuskasus yang telah kami uji, ada cukup banyak kesepakatan di antara stakeholder (di Kamerun dan Kalimantan).

Dalam contoh Kamerun di bawah, setiap kelompok etnis, kecuali Bamileke, menerima urutan peringkat dari kelompok yang didaftar ${ }^{14}$. Bamileke merupakan satu-satunya suku yang berasal dari kawasan yang berbeda, yang memiliki nilai-nilai yang secara lokal diakui berbeda. Oleh karena itu, ini merupakan suatu hasil yang penting dari suatu studi. Dari pertanyaan tentang kesepakatan atas hak-hak dan tanggung jawab stakeholder yang

${ }^{14}$ Ini tidak terjadi di dekat Kawasan Lindung Dja, walaupun hasil pemeringkatan tidak terlalu berbeda antar kelompok. Para pemimpin tradisional secara konsisten dianggap paling penting dan pihak-pihak pemerintahan memiliki kedudukan penting dalam setiap kelompok, kecuali untuk kelompok orang-orang pygmi (Tchikangwa dkk. 1998). 
relevan (Kriteria 2.3), kami dapat memberikan skor kelestarian agak tinggi (mungkin 8) dalam lembar isian induk K\&I.

Anda juga dapat mengetahui ada atau tidak pengakuan pengelola hutan terhadap berbagai peran stakeholder lainnya dalam pengelolaan hutan (Indikator 2.2.4). Untuk mengetahuinya perlu melihat persepsi para pengelola HPH (tidak dilakukan dalam contoh yang diberikan di bawah) untuk melihat bagaimana persepsi mereka tentang kepentingan stakeholder lainnya. Bila para pengelola berpendapat bahwa kepentingan masyarakat lokal dan para pekerjanya sangat rendah, mungkin akan dihasilkan skor 1 atau 2. Skor kelestarian tertinggi (10) pada indikator ini akan diperoleh bila stakeholder lokal (misalnya, masyarakat lokal, para pekerja lokal, para pengelola perusahaan HPH lokal) semua mendapat peringkat kepentingan yang agak tinggi daripada para pengelola hutan.

Anda kemudian akan merata-ratakan skor Anda dengan masing-masing kriteria pada lembar isian induk untuk memperoleh semua skor kelestarian yang berkaitan dengan Prinsip 2 .

\section{WAKTU YANG DIPERLUKAN}

Di Kamerun, Tiani dkk. (1997) melaporkan bahwa untuk melakukan versi yang lebih lama dalam studi ini diperlukan waktu tujuh hari untuk peneliti dan sepuluh hari untuk asisten. Sardjono dkk. (1997) melaporkan bahwa diperlukan rata-rata antara 7 dan 11 menit untuk setiap peserta (total 540 menit dalam satu lokasi, dan 230 menit untuk lokasi lain). Brocklesby dkk. (1997), yang melakukan wawancara kelompok, mengatakan bahwa dibutuhkan waktu antara 25 dan 45 menit untuk tiap kelompok, dan untuk kelompok wanita waktunya lebih lama. 


\section{FORMULIR SAMPEL PENYORTIRAN KARTU SKOR DAN}

ANALISISNYA

\section{FORMULIR SAMPEL - PENYORTIRAN KARTU SKOR}

[diterjemahkan dan direvisi dari pengujian awal Danau Sentarum]

\section{Latihan Penyortiran Kartu}

Jender

Etnis

Pekerjaan :

Umur
Desa

Wawancara :

Tanggal :

1. Siapa yang paling penting dihubungi ketika Anda memerlukan informasi tentang ikan?

2. Siapa yang paling penting dihubungi bila Anda mencari rotan?

3. Siapa yang paling penting dihubungi bila aturan-aturan perlu diubah?

4. Siapa yang paling penting dihubungi bila Anda mempunyai masalah dengan perusahaan $\mathrm{HPH}$ ?

\section{$\{1$ = terpenting, 2 = terpenting kedua, dll. $\}$}

\begin{tabular}{|l|c|c|c|c|l|}
\hline \multirow{2}{*}{ Stakeholder } & \multicolumn{4}{|c|}{ Siapa yang paling penting dihubungi } & \multirow{2}{*}{$\begin{array}{c}\text { Rata-rata } \\
\text { peringkat }\end{array}$} \\
\cline { 2 - 6 } & $\begin{array}{c}\text { P. 1 } \\
\text { (ikan) }\end{array}$ & $\begin{array}{c}\text { P. 2 } \\
\text { (rotan) }\end{array}$ & $\begin{array}{c}\text { P. 3 } \\
\text { (aturan) }\end{array}$ & $\begin{array}{c}\text { P. 4 } \\
\text { (masalah) }\end{array}$ & ( \\
\hline Desa Anda & & & & & \\
\hline Desa lain & & & & & \\
\hline Pemerintah & & & & & \\
\hline HPH & & & & & \\
\hline Proyek Konservasi & & & & & \\
\hline Pedagang & & & & & \\
\hline
\end{tabular}




\section{Hasil Penyortiran Kartu Skor (Contoh Kamerun)}

M. Edouga Christine, Bassanaga Simon dan François Tiayon di Wijma Sawmill (30 Oktober 1996)

\begin{tabular}{|l|c|c|c|c|c|c|}
\hline $\begin{array}{c}\text { Rata-rata Pilihan } \\
\text { Kepentingan }\end{array}$ & $\begin{array}{c}\text { Jum lah total } \\
(\mathrm{n}=14)\end{array}$ & $\begin{array}{c}\text { B ulu } \\
(\mathrm{n}=4)\end{array}$ & $\begin{array}{c}\text { Fang } \\
(\mathrm{n}=3)\end{array}$ & $\begin{array}{c}\text { Bassa } \\
(\mathrm{n}=3)\end{array}$ & $\begin{array}{c}\text { K wassio } \\
(\mathrm{n}=3)\end{array}$ & $\begin{array}{c}\text { B am ileke } \\
(\mathrm{n}=1)\end{array}$ \\
\hline Pegawai kehutanan & 1,95 & 1,69 & 1,58 & 2,58 & 1,83 & 2,50 \\
\hline Desa (Bantu) Anda & 2,80 & 2,75 & 2,92 & 2,67 & 3,42 & 1,25 \\
\hline HPH & 3,75 & 3,75 & 3,75 & 3,33 & 3,67 & 5,25 \\
\hline Tropenbos & 4,02 & 4,00 & 3,67 & 3,75 & 3,83 & 6,50 \\
\hline Desa (Bantu) lain & 4,25 & 4,13 & 4,42 & 3,92 & 4,67 & 4,00 \\
\hline Kamp orang kerdil & 5,21 & 5,44 & 5,42 & 5,58 & 5,00 & 3,25 \\
\hline Pedagang & 5,96 & 6,19 & 6,17 & 6,08 & 5,58 & 5,25 \\
\hline
\end{tabular}




\section{METODE KONTINUUM ITERATIF (MKI)}

Seperti yang dijelaskan dalam Bagian B dari panduan ini, kami menemukan bahwa metode ini sesuai dan sangat membantu peneliti yang terlatih dalam bidang antropologi; metode ini kurang dikenal dan lebih sulit untuk para biologiwan. Dalam metode ini diperlukan penilai yang berfungsi sebagai suatu alat yang sensitif dan kompleks, dan yang harus menyadari pengamatannya dan kesimpulan-kesimpulan yang diambilnya tentang sistem-sistem lokal yang sedang dinilai. Semakin banyak pengalaman dan ketrampilan penilai dalam mengamati peserta maka hasil-hasilnya akan lebih dapat dipercaya. Panduan yang bermanfaat untuk melakukan pengamatan peserta dapat diperoleh, misalnya dalam Fetterman (1993); Kleinman dan Copp (1993), Spradley $(1979,1980)$ dan Wolcott (1995).

\section{TUJUAN}

Untuk membantu pengumpulan data kualitatif secara sistematis tentang berbagai hak dan tanggung jawab untuk mengelola hutan secara bersama dan adil (khususnya Prinsip 2). 


\section{FORMULIRSAMPELMKI}

\section{FORMULIRMETODE KONTINUUMITERATIF(MKI)}

\section{'Hak dan kemampuan mengelola hutan secara bersama dan adil'}

tidak berarti

berarti

21 Juni 1996 [contoh dari catatan lapang Carol J. Pierce Colfer]

Sistem ini bagi saya menunjukkan beberapa tanda kemerosotan. Penduduk telah sedikit banyak meniadakan batas-batas wilayah mereka dengan dan dengan demi kepentingan

'kesatuan'. Dapat berarti sebuah standarisasi pengelolaan oleh sistem sungai???

Juga tidak ada KN (kepala nelayan), sehingga 'suara' penduduk tidak terdengar atau terpencarpencar.

Tampaknya tidak ada penduduk lain dari luar yang sekarang lebih berkuasa. Hampir tidak ada interaksi dengan proyek konservasi, semua HPH telah berhenti beroperasi.

3 Juli 1996 [ contoh dari catatan lapang Emily Harwell]

Sistem pengelolaan lokal dan hak-hak terhadap akses diakui paling sedikit secara lisan atau basa-basi. HPH lebih berada dalam kendali dibandingkan dengan HPH lain dalam kawasan karena tekanan lokal dari para pemilik HPH sebagai kerabat dan dari juru bicara untuk hakhak lokal. Namun, ada ketidakpuasan lokal terhadap praktek-praktek HPH yaitu karena mereka tidak memenuhi janji terhadap penggunaan hutan setara untuk semua orang (kegiatan-kegiatan penebangan di pinggir sungai, pembakaran kamp di

Di lain pihak, kunjungan ke kamp HPH B menunjukkan banyak peningkatan produksi pohonpohon karet untuk kegunaan lokal. Penanaman pohon karet agaknya akan menjamin hak-hak lokal terhadap lahan yang kegunaan lahannya lebih 'lestari' daripada ladang (dalam persepsi aparat pemerintah). Keadaan kamp yang tampak teratur baik menunjukkan ada yang memantau kegiatan-kegiatan di sini.

Obsesi HPH tentang 'penebangan liar' menekankan anggapan bahwa hak mereka atas lahan terhadap sumber daya hutan lebih kuat (hak-hak yang sudah ada sebelumnya atau lainnya) daripada hak-hak lokal lainnya.

Pertimbangkan peran wanita dan pria dalam pemantauan kepatuhan terhadap peraturan, pemecahan konflik, pelibatan pengetahuan indijenus, dan pengendalian arah dan kecepatan perubahan sosial. 


\section{PANDUAN BAGI PENELITI UNTUK MENILAI PARTISIPASI}

Awalnya metode ini dirancang berdasarkan asumsi yang tidak akurat: Bahwa penduduk lokal akan berpartisipasi dalam pengelolaan hutan oleh $\mathrm{HPH}$. Akan tetapi, dalam pengujian kawasan kami, kebanyakan kegiatan pengelola sehari-hari dilakukan oleh penduduk lokal. Beberapa anggota tim menemukan bahwa pertanyaan-pertanyaan yang didaftar dalam panduan bagi peneliti membantu dalam mempertahankan fokus anggota tim terhadap isu-isu penting. Pertanyaan-pertanyaan ini juga dapat membantu para penilai baru untuk waspada terhadap isu-isu setempat yang dapat mempengaruhi kelestarian dan kesejahteraan manusia. Beberapa anggota tim menggunakan metode ini dalam hubungannya dengan MKI (dijelaskan di atas).

\section{TUJUAN}

Untuk memandu penilaian yang berkaitan dengan Prinsip 2, hak dan kemampuan untuk mengelola hutan secara bersama dan adil.

\section{PESERTA}

Walaupun beberapa peneliti telah memberikan formulir (lihat bawah) kepada penduduk yang cerdas di lokasi penilaian, kebanyakan mereka menyimpannya untuk digunakan sendiri.

\section{BAHAN}

Formulir 'Panduan bagi Peneliti Mengenai Usulan Empat Fungsi Partisipasi'. 


\section{METODE}

Metode ini terdiri dari bahan bacaan panduan peneliti yang terus mengingatkan pertanyaan-pertanyaan, dan mengisi jawaban-jawaban pertanyaan dengan semakin berkembangnya pemahaman mereka. Informasi yang dikumpulkan secara informal dalam konteks metode-metode sebelumnya dapat digunakan untuk menjawab pertanyaan-pertanyaan ini. Panduan peneliti juga mungkin digunakan untuk melakukan wawancara dengan penduduk dalam kawasan. Kami juga telah memberikan panduan bagi peneliti cendekiawan-cendekiawan lokal.

\section{ANALISIS DAN PEMBERIAN SKOR}

Seperti metode-metode lain, kriteria dan indikator yang sedang dinilai perlu terus diingat. Pertanyaan-pertanyaan tersebut, bila dijawab, akan sangat membantu untuk membuat kesimpulan tentang K\&I (ilustrasi K\&I ditunjukkan dalam tanda kurung setelah masing-masing pertanyaan-walau mungkin berbeda-beda menurut lokasinya). Bukti dan kasus-kasus dapat dimasukkan dalam lembar isian induk di bawah kriteria atau indikator dan dibuat skor (seperti sebelumnya, dari 1 untuk yang tidak lestari hingga 10 untuk yang lestari).

\section{WAKTU YANG DIPERLUKAN}

Waktu di lapang untuk metode ini diperkirakan satu minggu hingga satu bulan, dan dalam jangka waktu ini para peneliti dapat memahami isu-isu yang terdaftar. Jawaban sebenarnya untuk pertanyaan-pertanyaan itu membutuhkan waktu sekitar satu jam. 


\section{SAMPEL PANDUAN BAGI PENELITI}

[Contoh disadur dari Pengujian awal Danau Sentarum, Kalimantan Barat, Indonesia]

Pertanyaan-pertanyaan di bawah diikuti dengan contoh-contoh yang terkait dalam tanda kurung; dan kriteria dan indikator yang terkait dalam tanda kurung.

\section{Panduan bagi Peneliti Mengenai Usulan Empat Fungsi Partisipasi}

\section{Mengurangi ketidakpatuhan terhadap peraturan-peraturan}

1. Apakah penduduk (pria, wanita, tua, muda) menyadari adanya peraturan-peraturan yang harus dipatuhi oleh berbagai perusahaanperusahaan $\mathrm{HPH}$ ?

[misalnya, batas-batas penebangan yang diijinkan, diameter minimum, penanaman kembali, upah minimum, aturan keselamatan, jarak dari sungai, limbah, syarat perencanaan]

$$
\text { [I. 1.1.2; K. 2.2; I. 1.2.3; I. 1.3.5; I. 2.3.1; I. 3.2.3] }
$$

2. Apakah penduduk lokal melihat atau mendengar berbagai pelanggaran oleh perusahaan-perusahaan HPH di dalam kawasan hutan? [misalnya, melihat pelanggaran-pelanggaran batas, melihat kayu yang masih terlalu muda atau spesies yang salah, praktek-praktek yang boros, praktek-praktek yang merusak lingkungan, penggunaan bahan-bahan kimia; mengetahui tentang rencana-rencana perusahaan sebelum pelaksanaan]

[I. 1.1.2; K. 2.2; K. 2.3; I. 1.1.1; I. 2.2.1] 
3. Apakah penduduk melaporkan berbagai pelanggaran? Kepada siapa? [misalnya, kepada kepala desa, kepada temenggung, kepada aparat Departemen Kehutanan dan Perkebunan, kepada pemerintah daerah, kepada KSDA, petugas Dinas Perikanan, kepada berbagai LSM] [I. 1.1.2; K. 2.3]

4. Apakah ada sanksi-sanksi yang diberikan jika terjadi berbagai pelanggaran? Oleh siapa?

[misalnya, denda, pemberhentian pekerja, pencabutan ijin HPH, ganti rugi kerusakan; melalui peradilan, kesepakatan di antara stakeholder, aparat Departemen Kehuntanan dan Perkebunan]

[I. 1.1.3; I. 1.1.4; K. 2.3; I. 1.2.4]

Mengurangi konflik sumber daya hutan/mengubah sumber daya hutan untuk digunakan bersama

1. Jenis-jenis masalah apa saja yang terjadi antara perusahaan HPH dengan penduduk lokal?

[misalnya, persediaan air tercemar bahan-bahan kimia, melanggar batasbatas, penggunaan lokasi-lokasi yang dikeramatkan, efek-efek yang merugikan karena kehadiran para pendatang terhadap budaya lokal; efekefek terhadap perikanan/perburuan; keributan]

[I. 1.1.3; I. 1.1.4; I. 2.2.4; I. 2.2.5; I. 3.3.1; I. 3.3.2; I. 2.2.1; K. 3.2]

2. Jenis-jenis masalah apa saja yang terjadi antara perusahaan $\mathrm{HPH}$ dengan para pekerja?

[misalnya, pekerjaan yang sedikit bagi penduduk lokal, kondisi-kondisi pekerjaan yang tidak aman, tidak membayar gaji/upah]

[K. 1.2; I. 2.1.1; I. 3.2.3] 
3. Apakah masalah-masalah diselesaikan dengan baik dan memuaskan? Bagaimana dan apakah dapat diandalkan?

[misalnya, pengadilan, negosiasi-negosiasi, penengah, kesepakatan tentang berbagai hak dan tanggung jawab dari masing-masing stakeholder]

[I. 1.1.4; I. 1.2.1; I. 2.3.1; I. 1.1.3]

\section{[Isu-isu tentang Suara]}

1. Dapatkah penduduk lokal menyebutkan pembuat-keputusan dalam perusahaan $\mathrm{HPH}$ ? (pria, wanita, tua, muda) [misalnya, satu atau dua orang penting, banyak orang] [K. 2.1]

2. Dalam konteks apa penduduk dari masyarakat berinteraksi dengan pegawai penting perusahaan HPH? Siapa? Bagaimana, seberapa sering? [misalnya, pertemuan-pertemuan resmi, pertemuan-pertemuan yang sering, tetangga-tetangga, pemasok barang kepada perusahaan, bekerja sebagai pegawai] [K. 2.1; K. 2.2: I. 1.1.3; I. 1.2.2; I. 3.2.2; I. 3.3.2]

3. Bagaimana penduduk lokal dapat menyampaikan harapan-harapan mereka? (pria, wanita, tua, muda) [misalnya, pertemuan-pertemuan resmi, perwakilan kepada perusahaan, 'program panduan pengembangan desa' dari HPH, wakil-wakil lembaga kehutanan] [K. 2.1; I. 2.2.5; I. 1.2.1]

4. Apakah sikap-sikap anggota perusahaan mendukung masyarakat lokal untuk memberikan masukan? 
[misalnya, menunjukkan hormat, pengetahuan bahasa-bahasa daerah, menghargai masukkan secara lisan, tanda-tanda bahwa mereka mencari masukkan, meyakinkan pengakuan hak-hak pria dan wanita lokal untuk berpartisipasi; rasa takut pada kedua pihak; menunjukkan penghargaan penduduk lokal terhadap pegawai perusahaan]

[I. 2.1.3; I. 2.2.4; I. 3.3.1; I. 3.3.2]

\section{Mengendalikan arah atau kecepatan perubahan gaya hidup masyarakat lokal yang terkait dengan hutan}

1. Dalam hubungan dengan perusahaan $\mathrm{HPH}$, pengaruh apa yang dirasa merugikan gaya hidup lokal?

[misalnya, migrasi masuk oleh kelompok-kelompok etnis yang berbeda (konflik antar etnis meningkat, persaingan), pelacuran, kawin di luar nikah dengan wanita lokal, anak-anak muda yang terbawa oleh budaya asing dan godaan-godaan baru, ketergantungan sistem ekonomi lokal terhadap perusahaan, hilangnya alternatif-alternatif ekonomi, ketergantungan pada perusahaan meningkat, hilangnya keragaman sebagai dasar subsistensi]

[I. 1.1.5; I. 1.2.4; I. 3.3.3]

2. Mekanisme-mekanisme apa yang ada untuk mengatasi pengaruhpengaruh yang merugikan?

[misalnya, pertemuan-pertemuan tetap, pegawai perusahaan HPH mau menerima 'program panduan pengembangan desa', pegawai-pegawai Departemen Kehutanan dan Perkebunan mendapat mandat untuk mengatasi berbagai masalah; hukum yang adil dan peradilan dapat dijangkau]

[I. 1.1.3; I. 1.2.1; I. 2.1.2] 


\section{Menyediakan pengetahuan untuk digunakan dalam pengelolaan hutan}

1. Pengetahuan lokal apa saja yang ada dan yang dapat digunakan dalam pengelolaan hutan?

[misalnya, pengakuan jenis lokal, pengetahuan pola pertumbuhan jenis lokal, pemahaman sistem subsisten penduduk lokal dan 'modal sosial', pengertian berdasarkan pengalaman tentang arah perubahan sejarah lingkungan]

[K. 1.1; I. 2.2.3; I. 3.3.2]

2. Bagaimana pengetahuan lokal ini dimasukkan ke dalam pengelolaan hutan?

[misalnya, penduduk lokal mengetahui rencana-rencana perusahaan (peta-peta pembatas, rencana penebangan, rencana pembangunan jalan); perusahaan memiliki data survei dasar atau indikator lain sistem-sistem pengetahuan lokal; staf pengelolaan atau pegawai Departemen Kehutanan dan Perkebunan mengaku hak-hak penduduk terhadap manfaat dan dapat menyuarakannya; pengunaan hasil-hasil hutan mencerminkan kompromi bersama antara keperluan penduduk dengan perusahaan HPH (bila mereka konflik)]

[K. 2.2; K. 3.3] 


\section{Daftar Pustaka}

Brocklesby, M. A., P. Etuge, G. Ntube, J. Alabi, M. Anje, V. Bau Bau, dan J. Molua. 1997. CIFOR Cameroonian test of social methods for assessing criteria and indicators for sustainable forest management. Mt. Cameroon Project, Limbe, Cameroon. CIFOR Report, Bogor, Indonesia.

Colfer, C.J.P. 1997. A test of social science assessment methods. CIFOR methods testing manual. CIFOR, Bogor, Indonesia.

Colfer, C.J.P. dan R.L. Wadley. 1996. Assessing ‘participation' in forest management: Workable methods and unworkable assumptions. CIFOR Working Paper No. 12. CIFOR, Bogor, Indonesia.

Colfer, C.J.P., dengan R. Prabhu, M. Günter, C. McDougall, N. M. Porro, dan R. Porro. 1999. Who counts most? Assesing human well-being in sustainable forest management. The Criteria \& Indicators Toolbox Series No. 8. CIFOR, Bogor, Indonesia.

Colfer, C.J.P., M.A. Brocklesby, C. Diaw, P. Etuge, M. Günter, E. Harwell, C. McDougall, N.M. Porro, R. Porro, R. Prabhu, A. Salim, M.A. Sardjono, B. Tchikangwa, A.M. Tiani, R.L. Wadley, J. Woelfel dan E. Wollenberg. 1999. The BAG (Basic assessment guide for human well-being). The Criteria \& Indicators Toolbox Series No. 5. CIFOR, Bogor, Indonesia.

Diaw, C., R. Oyono, F. Sangkwa, C. Bidja, S. Efoua dan J. Nguiebouri. 1998. Social science methods for assessing criteria and indicators of suatainable forest management: A report of the tests conducted in Cameroon humid forest benchmark and in the Lobe and Ntem River basins - Part 1. CIFOR Report. Bogor, Indonesia. 
Fetterman, D. 1993. Speaking the language of power: Communication, collaboration, and advocacy (Translating ethnography into action). The Falmer Press, Washington,DC.

Kleinman, S. dan M. Copp. 1993. Emotions and fieldwork. Qualitative Research Methods Series 28. Sage Publications, Newbury Park, CA.

Poffenberger, M. dan B. McGean. 1993a. Community allies: Forest comanagement in Thailand. Center for Southeast Asia Studies, Berkeley, CA.

Poffenberger, M. dan B. McGean. (eds.) 1993b. Upland Philippine communities: Guardians of the final forest frontiers. Center for Southeast Asia Studies, Berkeley, CA.

Perez, L. M. 1996. Analysis of social elements in forestry certification. Proceedings of UBC-UPM Conference on the Ecological, Social and Political Issues of the Certification of Forest Management. Selangor, Malaysia. h. 147-165.

Porro, R. dan N.M. Porro. 1998. Methods for assessing social science criteria and indicators for the sustainable management of forests: Brazil test. CIFOR Report, Bogor, Indonesia.

Salim, A., dan Colfer, C.J.P., dengan McDougall, C. 199. The Scoring and analysis guide for assessing human well-being. The Criteria and Indicator Toolbox Series No. 7. CIFOR, Bogor, Indonesia.

Sardjono, M.A., E. Rositah, A. Wijaya, dan E.M. Angie. 1997. A test of social science assessment methods concerning indicators and criteria for sustainable forest management in East Kalimantan. CIFOR Report. CIFOR, Bogor, Indonesia. 
Spradley, J. 1979. The ethnographic interview. Harcourt Brace Jovanovich College Publishers, New York.

Spradley, J. 1980. Participant observation. Harcourt Brace Jovanovich College Publishers, New York.

Tchikangwa, N.B., dengan S. Sikoua, M. Metomo dan M.F. Adjudo. 1998. Test des méthodes en sciences sociales de vérification des critères et indicateurs d'aménagement durable des forêts: Périphérie est de la Réserve du Dja (SudCameroun). CIFOR Report. CFOR, Bogor, Indonesia.

Tiani, A. M., dengan E. Mvogo Balla, A. Oyono dan N. Kenmegne Diesse. 1997. A test of social science assessment methods (near Mbalmayo, Cameroon). CIFOR Report. CIFOR, Bogor, Indonesia.

Woelfel, J.K. 1998. User's Guide CatPac II version 2.0. Rah Press, Amherst, NY.

Wolcott, H. 1995. The art of fieldwork. Altamira Press, Walnut Creek, CA.

Wollenberg, E. 1997. Sampling Stakeholders. In: Colfer, C.J.P. (ed.) A test of social science assessment methods. CIFOR methods testing manual. CIFOR, Bogor, Indonesia.

World Resources Institute (WRI). 1990. Participatory Rural Appraisal Handbook. WRI, Washington, DC. 


\section{Sistem CGIAR}

The Consultative Group on International Agricultural Research (CGIAR) adalah suatu asosiasi informal yang terdiri dari 41 organisasi donor dari sektor publik dan swasta yang mendukung jaringan enam belas lembaga penelitian internasional di bidang pertanian, di mana CIFOR merupakan anggota terbaru. Asosiasi ini didirikan pada tahun 1971. Pusat-pusat CGIAR merupakan bagian sistem penelitian global di bidang pertanian yang berusaha menerapkan kemampuan ilmiah internasional untuk menyelesaikan masalah-masalah yang dihadapi oleh masyarakat miskin di dunia.

\section{CIFOR}

CIFOR adalah bagian sistem CGIAR dengan tugas khusus untuk menanggapi kepedulian global tentang dampak kerusakan dan kehilangan hutan terhadap kondisi sosial, lingkungan dan ekonomi masyarakat. CIFOR beroperasi melalui berbagai kemitraan yang sangat terdesentralisasi dengan lembaga-lembaga dan/atau individu terpenting di seluruh negara industri dan negara yang sedang berkembang. Sifat dan jangka waktu kemitraan ini ditentukan oleh masalahmasalah penelitian khusus yang dihadapi. Agenda penelitian ini terus-menerus dikaji dan selalu mengalami perubahan ketika para mitra menemukan berbagai masalah dan peluang baru. 


\section{Panduan Pendamping Penilaian Dasar Kesejahteraan Manusia}

dirancang untuk melengkapi Panduan Penilaian Dasar (PPD). Panduan Pendamping Penilaian Dasar (PPPD) dirancang untuk digunakan oleh para ilmuwan sosial yang menganggap PPD agak terlalu preskriptif. Bagi para ilmuwan nonsosial, delapan metode yang disajikan mungkin dirasa lebih sulit, atau dalam beberapa kasus metode yang dibahas dapat menggantikan dengan satu atau beberapa metode yang disajikan dalam Panduan Penilaian Dasar (PPD). Selanjutnya, Panduan Cara Pemberian Skor dan Analisis untuk Menilai Kesejahteraan Manusia membantu para pengguna dalam melakukan penilaian aktual K\&l sosial, berdasarkan hasil-hasil dari metode ini. 